\title{
Relationship Between Types of Intelligence And Career Choice Among Undergraduate Students Of Maseno University, Kenya
}

\author{
Richard Juma Atela ${ }^{1}$, Prof. Lucas Othuon (Phd $)^{2 *}$, Prof. John .O. Agak (Phd) ${ }^{3}$ \\ 2. School of Education, Maseno University, P.O Private Bag, Maseno, Kenya \\ 3. School of Education, Maseno University, P.O Private Bag, Maseno, Kenya \\ *E-mail of corresponding Author-lothuonus@yahoo.com \\ The research is self funded by the student-author-Richard Juma Atela
}

\begin{abstract}
Training institutions in most parts of the world place high premium on those who excel in examinations based on scholastic intelligence. In Kenya, students are admitted into available undergraduate degree programmes in public universities based on their performance in Kenya Certificate of Secondary Education (KCSE). Yet, the Bachelor of Education (B.Ed) degree programmes offered in the School of Education at Maseno University have a strong bearing on types of human intelligence and not all the students admitted can fit in them. Academic qualification remains a challenge to a majority of students $(79.4 \%)$ in choosing a career; hence a significant number $(94 \%)$ of students end up settling for what is available rather than their choice. Apparently, limited attention has been given to exploring the relationship between students' innate occupational skills and interests hence the current low $(7 \%)$ college career satisfaction level. The purpose of the study therefore, was to establish the types of intelligence and their relationship with career choice among first-year B.Ed students of Maseno University, Kenya. The objectives of the study were to establish the types of intelligence across among male and female students and to determine the degree of relationship between types of intelligence and career choice. The study was guided by the Howard Gardner's Multiple Intelligence Theory (1983). Correlation and descriptive survey designs were adopted for the study. The target population consisted of the 490 first-year B.Ed students admitted in the Academic year 2011/2012 in the School of Education. The study sample consisted of 220 firstyears B.Ed students drawn using proportionate stratified sampling. Data was collected by use of Questionnaire and document analysis guides. The questionnaire was piloted using $10 \%(\mathrm{n}=49)$ of the study population. Pearson Product Moment correlation was used to determine reliability at alpha level 0.05 . The questionnaire had an acceptable reliability index of 0.84 . Quantitative data was coded and analyzed using descriptive statistics such as mode, frequency counts and percentages. A type of intelligence was established using percentages and mean. Further, gender difference in types of intelligence was examined using mean gender differences. Further, the degree of relationship between types of intelligence and career choice was established using cross tabulation with chi-square test and Likelihood Ratio test. Qualitative data was transcribed into text form of emerging themes and reported. The results showed that first-year students scored very high in interpersonal intelligence $(90.9 \%)$ and relatively lower on visual-spatial intelligence $(75.5 \%)$. The study found significant difference between male and female in logical/mathematical $(d f 35, p=0.005)$, verbal/linguistic $(d f 38, p=0.004)$ and existentialist $(d f 34, p$ $=0.000)$, music-rhythmic ( $d f 37, p=0.012)$ and bodily-kinesthetic $(d f 33, p=0.015)$ intelligence in favour of males and no significant difference in visual-spatial $(d f 33, p=0.06)$, interpersonal $(d f 47, p=0.142$,), intrapersonal ( $d f 19, p=0.408)$ and naturalistic $(d f 34, p=0.16)$ intelligence domains. Results of the chi square test show that there is a significant relationship $(\mathrm{r}=.182, \mathrm{p}<.000)$ between types of intelligence and career choice. The results of the likelihood ratio test show very high $(\mathrm{p}<.000)$ degree of relationship between types of intelligence and career choice. The following conclusions are drawn; Students at Maseno University can be classified into the nine Gardner's intelligence types; Gender differences exist in specific types but not all types of intelligence and that there is a significant high degree of relationship $(r=.182, p<.000)$ between types of intelligence and career choice. The study recommended that the need to investigate factors at the university environment which influences the development of multiple intelligence among male and female students. Significantly, the study provides a useful guide to students, education policymakers and university staff for career choice, placement training and retention efforts.
\end{abstract}

Key words: Multiple Intelligence, Gender, Career choice, degree programme

DOI: $10.7176 / \mathrm{JEP} / 10-33-14$

Publication date: November $30^{\text {th }} 2019$

\section{Introduction}

Academic results remain the main promotional devices in education systems at all levels of education in most parts of the world and a means of placing students in broad superficial intelligent-quotient (I.Q) based career training groups. Shearer (2006) argue that students learn at a very early age to sort themselves into these same categories by observing which students are labeled as smart in the classroom. The reforms that have taken place 
in the education sector in the last three decades coupled with the rapid changes in the labour market have presented challenges and opportunities for relevant career counseling globally and locally to the increased number of universities and the number of students enrolling and graduating from the universities. (Organization for Economic Corporation Development, 2004).

Historically, students with average school grades and modest I.Q. scores were dissuaded from attending university education (Shearer, 2006). According to Shearer (2006), while many academic universities are resistant to the idea that their primary objective is to facilitate the vocational planning of students', they may be contributing to student attrition by being reluctant to recognize their students' intelligences but laying more emphasis on fostering students' career development. Thus university students with unique intelligences present a challenge to institutions that wish to maintain high academic standards and also serve students' career needs.

The establishment of a vocational identity in form of clear and stable picture of one's abilities is critical in the prevention of vocational crisis (Samora, 2012). This is more so because many programmes offered at the university have a strong bearing on types of human intelligence. Therefore if a university academic environment is to reward certain patterns of students' abilities, it's imperative that students choose or are admitted into degree programmes that are compatible with their unique types of intelligence. This is moreso because intelligence is not a single trait (Sternberg, 2003).

A type of intelligence is comprised of a set of specific skills that embody both convergent problems solving as well as divergent thinking abilities and has its own memory system with specific cerebral structures dedicated to processing its specific contents (Gilman, 2012). Gardner (2012) proposed nine types of intelligence possessed by human beings in varying degrees namely mathematical/logical, linguistic/verbal, bodily/kinesthetic visual/spatial, musical/rhythmic, interpersonal, intrapersonal, naturalist and existential. For example, interpersonal and intrapersonal intelligences are relating functions of the frontal lobes of the human brain (A1Sabbah, Al- Sabbah \& Abod, 2011). Hence a person may have all the multiple intelligences or some of them with varying degrees (Ozgen, Tataroglu \& Alkan, 2011; Ghazi, Shahzada, Gilani, Shabbir \& Rashid, 2011; Alghazo, Obeidat, Al-Trawneh \& Alshraideh, 2009). For example, Eid and Alizh, (2004) assert that a person can have extra ordinary linguistic intelligence but low musical intelligence. However, Okatcha Grigorenko, Nokes, Geissler, Kenny, Bundy and Sternberg (2012) opined that people may have relatively high levels of intelligence in an academic setting and yet show little in practical setting.

In the context of the growing interest in applying multiple intelligence theory in the educational settings, this study is different from other studies because it could be one of the few studies in Kenya that have addressed the types of intelligences and their relationships with career choice in the Kenyan context. This study focused on the nine types of intelligence among predominantly black students in an African University like Maseno University unlike some studies like Shearer (2009), Wilson, (2007), Green (2010) and Shiruffudin, (2010) and Ozgen et al (2011) which focused on specific multiple intelligences to discriminate people outside but within a mainstream culture.

Several studies have reported gender differences in specific cognitive abilities with some supporting females and others support males (Lin, 2009). According to Cooijmans (2013) sex differences in mental abilities are caused by hormonal differences (estrogen / testosterone) balances which work partly prenatally and partly after puberty. Females are slightly better than males at straight forward arithmetic (not complex mathematics). Females outscore males in perceptual speed with their advantage in such tasks as matching figures, clerical checking, speed and accuracy varying from .2 to .4 SD. Cooijman (2013) further found that males are better than females in spatial ability, mental manipulation of figures in two or more dimensions. The difference varies from .3 to .5 $\mathrm{SD}$. Males are better in numerical ability at .1 to.25 SD. while in spatial ability there are large differences favoring males.

As the industrial revolution has evolved into the information age dominated by science and technology, society has placed higher expectations on all students to achieve higher in core academic subjects such as languages, mathematics and sciences. Universities have also raised their entrance requirements and applied pressure to high schools to better prepare students in languages, sciences and mathematics (Shearer, 2009). For instance, The Sessional Paper No.1 of 2005 targeted an increase in the proportion of all students studying science related courses in Kenya to $50 \%$ with at least one third being women by the year 2010 . This ultimately disadvantages students of either gender who may lack the cognitive competencies in these fields of study (Kalambuka, 2010).. Although the above studies are significant to this study as they revealed gender differences in types of intelligence, most of the studies like Cooijmans, (2011) focused mainly on logical mathematical, linguistic, 
spatial and bodily-kinesthetic and not other significant MI profiles like existentialist, intrapersonal and naturalistic. Studies by Tirri, Nokelainen, and Ubani (2008) focused on preadolescents only in non-African populations hence was demographically limited.

For the purpose of this study, career choice refers to the B.Ed degree programmes in which the students are training in at Maseno University, Kenya. Maseno University offers five undergraduate B.Ed degree programmes namely B.Ed-Arts, B.Ed-Science B.Ed-Special Needs, B.Ed- Early Childhood development and Education and B.Ed- French in the School of Education (Academic Division, 2012). The modal students' admission grade in public universities is $\mathrm{C}+($ G.O.K, 2012). In most cases students who fail to attain the required points during the first selection are required to make a second selection based on courses available. The second selection process is used to allocate degree programs available. This means that a student may be allocated a degree program they did not intend to pursue in the initial stage of selection (Gallup, 2012). According to G.O.K, (2012) and Gallup (2012). the entry qualifications are useful for identifying admissible university students as well as for predicting their potential to achieve the expected learning outcome which have no correlation innate talents and gifts of the candidate (Obora, 2012). Yet academic qualification remains a challenge to $79.4 \%$ of students when making a career choice (Migunde, 2011). Interestingly, $85 \%$ of students in public universities are not studying degrees of their choice despite scoring well in KCSE while $96.1 \%$ are not allocated courses of their choice. This accounts for the current college career satisfaction low levels of 7\%. According to Wagah, Agak and Indoshi, (2010) education systems in Africa are too theoretical and academic, ignoring skills and practical abilities that would prepare youth for productive careers. Apparently, limited attention is given to exploring the relationship between students' unique abilities during their schooling years Interestingly, students always know, understand and have learned much more than they demonstrate on any tests (Lin, 2009). Hence majority of students end up in degrees they are not passionate about. According to Kalambuka (2010), learning institutions now operate in a Darwinian world where, the academically fit students survive, others flounder. The cost of dropping out, changing courses and not graduating in time is high as much as two thousand dollars (Allen \& Robbin, 2010). According to United States of America Department of Education (nces.ed.gov, 2010) students in four-year colleges, only $36 \%$ graduated in four years and about $40 \%$ dropped out. In Kenya, the Joint Admission Board (JAB) announced that more than five thousand candidates who sat KCSE in 2011 failed to fit in any of their degree choice hence pointing to something wrong about candidates' knowledge on career choices.

Gardner (2006) contends that there are a number of other unique human potentials and attention should be given to individuals who demonstrate skills such as like artists, naturalists, musicians, chess player, and athletes who pervade the culturally-fit occupational environments. Further vocational subjects like fine art, theatre arts and related occupations have sometimes been denigrated because the spatial, kinesthetic and other intelligences needed in these areas have not been recognized. According to Lenaghan (2000) as cited by Shiruffudin (2010), the interpersonal intelligence type is characterized by teaching, public speaking and leading. Wambugu (2010) asserts that some information technology professionals spare much thought about communication skills because they share their ideas visually and use flowcharts, blueprints, satellite images, and schematics. The old field leader of a sports team might not require a particular high I.Q especially if he or she is a talented athlete, experienced and knowledgeable of the sports (Reggio, Murphy, \& Pirozzolo, 2002). The epitomes of existentialist intelligence include the scientist Einstein and early philosophers like Aristotle, Confucius, Plato, and Socrates (Wilson, 2012).

Most of the studies done in Maseno University like focused on issues like quality assurance processes, market effectiveness of graduates Kimani, and Kinyanjui (2012). Interestingly, Gallup International (2012) surveyed why majority of students were dissatisfied with their career choices. Similarly, the G.O.K (2012) found that most teacher trainees do not have teaching as a first choice at all levels of teacher training and recommended the vetting of all trainees to establish their inner interests to teaching as career. This has provided a significant gap which the current study hopes to address.

The search for literature has also not yielded information on a similar research conducted to examine whether the undergraduate students in the B.Ed degree programmes possess the innate intelligences congruent to their career choices using Multiple Intelligence model or any other model. Similarly, no specific study based on other theoretical models has been found regarding the relationship between types of intelligence and any other degree programme. Previous studies in certain populations have suggested the need for a similar study in different cultures. Consequently, these types of intelligence largely remain untapped by Maseno University education and research and therefore widely unknown to most students (Acosta, 2012). 


\subsection{Statement of the Problem}

Studies conducted in Kenya reveal the need to help students acquire in-depth understanding of self in order to choose careers that best suit their skills and abilities and not just their scholastic intelligence. Further studies on occupational aspirations among students have indicated that there are no assessments done to determine alternative intelligence career abilities. With little self-knowledge and congruent career opportunities in the world of work, the students' end up in career choices which have apparently may have no correlation with their innate intelligences. The B.Ed programmes offered at Maseno University have a strong bearing on different types of intelligence and not every student undertaking them can fit in them. Considerable evidence also reveals that a B.Ed training programme does not fully exploit the innate abilities of university students enrolled in them. Significantly, academic qualification remains a major challenge $(79.4 \%)$ to a students' career choice. Yet, students are admitted into available degree programmes rather than their choice in the public universities based on their performance in national examination (KCSE). Majority $(94 \%)$ of students are not allocated courses of their choice while $85 \%$ are not studying for degrees of their choice despite scoring well in KCSE hence low (7\%) college career satisfaction levels. Apparently, limited attention has been given to exploring the relationship between students' unique types of intelligence and career choice. Apart from trying to change courses midway, getting supplementary examinations, and dropping out all-together, this can lead to prolonged completion durations. The students become disillusioned and often end up wasting time and resources passively training in disappointing and less motivating degree choices. This study will seek to fill the gap arising from several studies that have been carried out in Kenya which have recommended the need to determine whether the students are aware of their multiple intelligences and how these relate to their degree choice. Unfortunately, these types of intelligence are untapped in Maseno university B.Ed programmes training and research and most undergraduate students unaware of their existence. Hence the focus of this study was to establish the types of intelligence among male and female first-year B.Ed students and to determine the degree of relationship between their types of intelligence and career choice using Gardner's Multiple Intelligence Theory since no previous researches has been done on the basis of this theory among undergraduate B.Ed students of Maseno University, Kenya.

\subsection{Purpose of the Study}

The purpose of the study was to establish the relationship between Gardner's types of intelligence and career choice among male and female first-year B.Ed students of Maseno University, Kenya.

\subsection{Objectives of the Study}

Specifically, the study sought to;

1. Establish types of intelligence among first-year undergraduate students in the Bachelor of Education

degree programmes of Maseno University.

2. Establish gender difference in the types of intelligence among the first-year undergraduate B.Ed students of Maseno University.

3. Determine the degree of relationship between types of intelligence and career choice among the first-

year B.Ed students of Maseno University, Kenya.

\subsection{Research Questions}

The study was guided the following research questions;

1. What are the types of intelligence among first-year undergraduate students in the Bachelor of Education degree programmes of Maseno University?

2. How do male and female first year students differ in types of intelligence?

3. What is the degree of relationship between types of intelligence and career choice among first-year undergraduate students in the B.Ed programmes?

\subsection{Assumptions of the Study}

1. It is assumed that the B.Ed programmes being pursued by the undergraduate students are their ultimate career choice.

2. It is assumed that first year B.Ed students of Maseno University possess overlapping types of intelligence types.

\subsection{Scope of the Study}

The target population was first -year students and therefore the sample did not include all students in other academic years at Maseno University or in any other public university. The B.Ed. programmes were included in the scope of the study because of their strong bearing on multiple intelligence as reflected in the five cohorts in the B.Ed. programmes. Lastly, B.Ed. programmes are also a representative in study units either in sciences, humanities or languages. 


\subsection{Limitation of the Study}

Due to the uniformity and duplicity of the B.Ed programmes and courses in Kenyan public universities, the study was limited to only one public university, Maseno University. For comprehensive results all public, private universities and other institutions of higher should have been included in the study, but financial and other logistical constraints made it impossible to cover all institutions of higher learning in the country. The integration of (KUCCPS) regular and self-sponsored (Special) students posed a daunting limitation to administration of instruments as it was difficult to decipher the motives of the career choice. Further, cohorts may be difficult to isolate due to confounding variables like similarity in subject choices and common units. Since the study was done with large groups especially in the B.Ed Arts and B.Ed-Science, this may have obscured important individual and subgroup differences for groups with low enrolments like B.Ed-French.

\subsection{Delimitations of the study}

The population under consideration was drawn from one public university, Maseno University. The definition and classification of types of intelligence were drawn from tenets of Gardner's multiple intelligence classification only.

\subsection{Significance of the Study}

The concept of types of intelligence in relation to career choice would be timely for use by the education policymakers, university admission officers and lecturers in understanding their students' skills and provision of career education. Information about types of intelligence and career choice would inform recruitment, retention efforts and placement as the findings would hopefully help universities in adequately appraising students and matching their specific unique intelligences to a career choice. Although the study used B.Ed students as participants, the significance of this study could extend to other degree programmes. The career correlation model could be used to develop degree admission and revision model by Joint Admission Board and the Universities. Finally, it is hoped that the research findings would contribute to the existing knowledge in the field of intelligence and career choice as well as prompt further research in Kenya.

\subsection{Theoretical Framework}

The theoretical framework for this study is based on Howard Gardner's (1983) Multiple Intelligence (MI) Theory. The theory emphasize types of intelligence which are autonomous but interactive (Green, 2010; Gottfredson \& Duffy, 2008; Lulgjural \&Cooley, 2006; Shearer, 2006).

In this study, Howard Gardner's (1983) theory has been chosen because it is more unitary and culture-sensitive in intelligence grouping as compared to two-factor and triachic theories of Charles Spearman (1863-1945) and Robert Sternberg (1985). Multiple intelligence portends unique human potentials which drive individuals to congruent careers. Multiple intelligence activities have also been found to broaden the parameters of career choice (Mantazaris, 2012). Students training to be mathematicians or physicists, spend years sharpening their mathematical intelligence in a distinctive and logically relevant way. Naturalists are perfect in cataloguing information easily and show interest in fields like botany, zoology and biology (Ghazi, 2011). According to Morris (2004), the environmentally friendly consumer habits aims to capture human talent for ecological sensibility and understand the human connectivity with a complex ecosphere. Teachers and historians' need 3-D modeling and visualization to recreate historic characters while geography, physics and chemistry teachers can make these subjects interesting when teaching concepts like gravitational force and pressure using 3-D animation (Kariuki, 2011).

According to Gardner (1983) a successful attorney needs to possess skills of linguistic, logical-mathematical and interpersonal skills. To artists and pilots skills of spatial intelligence are essential although each tap into different domains of this intelligence such as map reading and spatial awareness for pilots, and aesthetic, design, color and form for the artists. (Gilman, 2012). Functional aspects visual artists and interior designers exemplify creative spatial thinking while successful architect will need both creative and technical accomplishment. Well-developed interpersonal intelligence promotes success in managing relationships hence this intelligence is a prerequisite for managerial and leadership careers (Gilman, 2012). According Saeedi, Pazvari, Masouleh, Mousavian (2012) and Yazdanimoghaddam, M. and Khoshroodi, B. S. (2010), successful teachers are also likely to utilize bodilykinesthetic intelligence to build effective communication with their students. A sitting or stationary teacher runs the risk of putting students to sleep as opposed to a teacher who makes the right body movements in the right time. Yazdanimoghaddam and Khoshroodi (2010) found that the linguistic and musical intelligence are the two main predictors of teacher efficacy. Furthermore, it is believed that individuals who have high levels of emotional intelligence will have higher levels of job satisfaction and organizational commitment that will make both their individuals and organizations more successful (Saeedi, Pazvari, Masouleh and Mousavian, 2012). 


\subsection{Definition of Terms}

For the purpose of the study, the pertinent terms are operationally defined below;

Career: A job, a profession, vocation, for which one is trained or is training and which one intends to follow for the whole of one's life

Career choice This is preferred occupational choice. For the purpose of this

study, career choice includes the undergraduate bachelor of

education degree programmes (B.Ed- Arts, B.Ed- Science, B.Ed-

Special Needs, B.Ed- ECDE and B.Ed- French) being pursued by

the students.

Degree program: This is the specific academic program of study a student is

pursuing. An entire training degree programme design made up of

course units, content, methodology and organization like B.Ed -

Science.

Gender The psychological features and sociological categories of males and females created by human cultures. In this study, gender refers to male and female first-year students of Maseno University.

Multiple Intelligences: Also referred to as types of intelligence based on Howard Gardner's (1983) classification. The different unique ways to demonstrate intellectual ability and benefit from the experience learn new ideas and sets of behavior in dealing effectively with ones environment.

\section{Types of Intelligence}

Cohen (2012) defines intelligence as a capacity of an individual to act purposefully, think logically and to deal with the environment. Many psychological studies suggest that intelligence is not a single trait (Sternberg, 2003 Nasser, Singal \& Abouchedid; 2006).

Mustafa, Jado and Onoz, (2014) investigated types of Multiple Intelligences among Undergraduate Students at Yarmouk University in Light of Gardner's Theory and results showed linguistic intelligence ranks first with mean scores of (9.97) and SD of (3.02), then came the intrapersonal intelligence with mean scores of (8.34) and a SD of (2.29), while the visual-spatial intelligence ranks last with mean scores of (6.98) and a SD of (3.68). The authors attributed these results to the focus of the educational systems in Jordan either in schools or in universities on developing linguistic intelligence among students through using teaching strategies based on exposition, lecturing, questioning, and dialogue as well as using verbal and written language in different types of assessment and evaluation.

Mahasneh (2013) conducted a study on the relationship between Multiple Intelligence and Self-efficacy among sample of Hashemite university students. The author sought to establish the multiple intelligence abilities of the undergraduate students. The student's means and standard deviations were calculated and reported mean and standard deviations of students' multiple intelligence. From sub-scales of the represent higher level of musical $(\mathrm{M}=2.70)$, verbal-linguistic $(\mathrm{M}=2.54)$, naturalist $(\mathrm{M}=2.52)$, visual $(\mathrm{M}=2.50)$, bodily-kinesthetic $(\mathrm{M}=2.46)$, logical $(M=2.42)$, intrapersonal $(M=2.42)$ existential $(M=2.40)$, understanding and interpersonal (2.16).

Hanafiye (2013) investigated the relationship between students' gender and intelligence types, the relationship between particular intelligence types and students' success in grammar, and writing in English as a foreign language among randomly selected 140 students from Islamic Azad University Tonekabon ranch, Iran. The analysis revealed that logical mathematical intelligence (mean: 3.88) was the leading intelligence among the students who participated in this study. The other dominant intelligence types were spatial intelligence (mean: 3.67), bodily-kinesthetic (mean: 3.66), interpersonal intelligence (mean: 3.61), and intrapersonal intelligence (3.54). These were followed by a considerably less common intelligences, namely linguistic intelligence (mean: 3.19) and musical intelligence (mean: 3.18). It is noteworthy that musical intelligence had the highest standard deviation, indicating a greater variation among the participants who showed tendency toward musical intelligence.

Al-Sabbah, et al (2011) measured the level of MI of students' from a sample of 13 out of a population of 206 Jordanian high schools. The results showed that students scored very high in mathematical intelligence (89.5\%), kinesthetic intelligence (79.5\%) and linguistic intelligence (79.4\%). However the students scored lower on musical intelligence $(29.6 \%)$ and natural intelligence $(26.5 \%)$. The authors attributed the low scores on musical and natural intelligences to the teaching of Islam which forbid the teaching of music while Muslims are required to be merciful towards animals. 
Ozgen et al (2011) examined the multiple intelligence domain and learning styles of pre service mathematics teachers studying in the Department of Secondary Mathematics Teachers Education at a public university in Turkey. Employing the survey model, the study was conducted with a sample of 243 (112 or 46.1\% males and 131 or $53.9 \%$ female) among first, second, third, fourth and fifth graders. The findings showed that pre service teachers had the highest logical-mathematical intelligence (mean $=28.89 ; \mathrm{SD}=5.31)$, moderate advanced levels in verbal-linguistic intelligence (mean=20.34; $\mathrm{SD}=4.82$ ), musical-rhythmical intelligence $($ mean $=20.05 ; \mathrm{SD}=$ $8.17)$, intrapersonal intelligence $($ mean $=23.72 ; \mathrm{SD}=4.81)$ and lowest in musical rhythmic intelligence $($ mean $=$ $20.05 ; \mathrm{SD}=8.17$ )

Shariffudin (2010) explored the pattern of multiple intelligence among high achievers from Maktab Rendah Sains MARA in Malaysia. The results on Multiple Intelligences showed that the high achievers possess the following intelligences; Musical/Rhythmic, 48\%; Logical/mathematical, (44.8\%); Existential, 41.6\%; Verbal/Linguistic (40.8\%); Visual -spatial, (39.2\%); Interpersonal, 29.6\%; Naturalist, 29.6\%; bodily-kinesthetic (36\%); Intrapersonal, 31.2\%; This implies that high achievers possess different types and levels in multiple intelligence domains.

Matto, Berry-Edwards, Hutchinson, Bryant and Waldbilling (2006) conducted an exploratory study at Virginia Commonwealth University to determine faculty perceptions of the importance and effectiveness of MI when used for social work practice and education. Results showed that most faculty members ranked their linguistic $(97.2 \%)$, intrapersonal $(94.3 \%)$, and bodily-kinesthetic $(89.7 \%)$ intelligences highest level of importance while logical- mathematical (29.4\%) was ranked as the lowest degree of importance.

Göğebakan (2003) examined how students' multiple intelligences differ in terms of grade level and gender. Students at the first grade level demonstrated strong preference for linguistic intelligence $(X=5,51 \mathrm{sd}=1,78)$ and logical mathematical intelligence $(X=4,81 \mathrm{sd}=1,95)$ and the two intelligences followed were spatial intelligence ( $X=4,35 \mathrm{sd}=1,47)$, and bodily kinesthetic intelligence( $X=4,31 \mathrm{sd}=1,62)$. The third grade students' most dominant intelligences were interpersonal ( $X=4,59 \mathrm{sd}=1,43)$, spatial ( $X=4,55 \mathrm{sd}=1,53)$, logical mathematical ( $X=4,50 \mathrm{sd}=2,09)$, and linguistic intelligence $(X=4,40 \mathrm{sd}=1,56)$. For the fifth grade students, interpersonal intelligence $(X=6,23 \mathrm{sd}=1,23)$ bodily-kinesthetic intelligence $(X=4,86 \mathrm{sd}=1,54)$, spatial intelligence $(X=4,31$ $\mathrm{sd}=1,22)$, musical intelligence $(X=3,54 \mathrm{sd}=1,21)$ were more dominant. For the students at the eighth grade interpersonal intelligence ( $X=6,44 \mathrm{sd}=1,73)$, bodily kinesthetic intelligence $(X=4,82 \mathrm{sd}=1,73)$, musical intelligence $(X=4,08 \mathrm{sd}=1,89)$ spatial intelligence $(X=3,81 \mathrm{sd}=1,60)$ were more dominant.

Okatcha, Grigorenko, Prince, Nokes, Geissler, Kenny, Bundy and Sternberg (2012) examined the organization of the concept of intelligence among the Luo people in Kenya and asserted that the concepts (Rieko, Luoro, Paro and Winjo) appear to form two latent structures; socio-emotional competence and cognitive competence. In yet another case study, Okatcha et al (2012) tested the notion that academic and practical intelligence are separable and distinct constructs and found that scores on the test of tacit knowledge correlated trivially or significantly negatively with measures of academic intelligence and achievement, even at odds with one another. This implies that a person's ability to function in the routine of daily life and solve any problems that occur therein constitute intelligence. Research findings among the Buganda cited by Reggio, Murphy and Pirozzolo (2002) revealed that the Buganda people of Uganda associate intelligence with careful and deliberate thought and considerations of many alternative solutions with slow internal examinations before sharing thoughts with others.

From the review of the related literature, it is obvious that there are many studies that have addressed the multiple intelligences theory in varied topics, levels and cultures. The results of these studies confirmed the effectiveness of these programs and strategies such as Al-Ahdal (2009), Khataybeh and Al-Bdor (2006), and AlAslani (2010), whereas, other studies focused on the relationships between multiple intelligences and some variables such as grade level, achievement, gender, mathematical thinking, professional tendency (Yamin, 2013), (Gogebanakan, 2003), and (Golam, 2011). Therefore, this study is different from other studies because it could be one of the few studies in Kenya that have addressed the types of multiple intelligences and their relationships with career choice on the university level in the Kenyan context. Apparently no study has been done in Maseno University on types of intelligence by use of established culture-fit model like MI. Okatcha et al (2012) focused on traditional populations and abilities and also sought to demystify intelligence as conceptualized in western context while Al-Sabbah focused on Arabic students only. Some studies Shearer (2009) and Wilson, (2007) focused on intrapersonal and existentialist intelligence respectively. Studies by Shearer, (2006), Green (2010) and Shiruffudin, (2010) did not address existentialist intelligence whereas Shearer (2006) and Ozgen et al (2011) focused on Math group only, this study will focus on multiple intelligence among first-year B.Ed students. In addition, standardized I.Q tests have been criticized to have a self-fulfilling effect, to be inconsistent with 
success, and to discriminate against people outside of mainstream culture hence the choice of Multiple Intelligences to establish the types of intelligence among first-year undergraduate B.Ed students of Maseno University.

\subsection{Gender Difference in the Types of Intelligence}

By and large, several studies have indicated the need for research in gender related differences in intelligence with several studies reporting gender differences in specific cognitive abilities (Lin, 2009; Wendy \& Johnson, 2007).

Mustafa, Jado and Onoz, (2014) investigated if there are there statistically significant differences in multiple intelligences abilities among undergraduate students of Yarmouk University attributed to the gender variable. Results showed that there are no statistically significant differences $(p=0.05)$ between the mean scores of the study sample on the intrapersonal intelligence while there are significant differences $(p=0.05)$ between the mean scores of the study sample on the rest of the intelligences attributed to the gender in favor of males on the logical mathematical, visual-spatial, and bodily-kinesthetic, and naturalistic intelligences, and in favor of females on the linguistic, interpersonal, and musical intelligences. The authors attribute these results to the nature of the cerebral anatomy of males that show superiority over females on the scientific abilities that rely on cognitive style field independence, while females rely on the cognitive style field-dependence.

Hanafiye (2013) further investigated whether there is a significant difference between female and male students in terms of their types of Intelligences. Results show that intrapersonal, linguistic, logical, and musical intelligences were more common among females. Further analysis of group difference revealed a significant difference between males and females only in linguistic intelligence $(\mathrm{p}<.02)$.

Shahzada, Ghazi, Khan, Iqbal and Shabbir (2011) investigated self-perceived Multiple Intelligences of 1st year male and female in all government degree colleges, session 2010, in Bannu district. Mean score of the male selfperceived verbal/linguistic intelligence is $\mathrm{M}=3.08$ and female $\mathrm{M}=3.41, \mathrm{SD}=.75, .65, \mathrm{P}$ value is .00 which is less than $\alpha 0.01$ which means that there is a significant difference between male and female self-perceived verbal/linguistic intelligence in favour of females. Mean score of the male self-perceived logical $/$ mathematical intelligence is $\mathrm{M}=3.12$ and female $\mathrm{M}=2.94, \mathrm{SD}=.89, .84, \mathrm{P}$ value is .00 which is less than $\alpha 0.01$ which means that there is a significant difference between male and female self-perceived logical $/$ mathematical intelligence in favour of males. Mean score of the male self-perceived visual/spatial intelligence is $\mathrm{M}=3.05$ and female $\mathrm{M}=3.24, \mathrm{SD}=.73, .63, \mathrm{P}$ value is .00 which is less than $\alpha 0.01$ which means that there is a significant difference between male and female self-perceived visual/spatial intelligence in favour of females. Mean score of the male self-perceived musical intelligence is $\mathrm{M}=2.05$ and female $\mathrm{M}=2.13, \mathrm{SD}=.68, .79, \mathrm{P}$ value is .11 which is greater than $\alpha .01$ which means that there is a no significant difference between male and female self-perceived musical intelligence. Mean score of the male self-perceived bodily/kinesthetic intelligence is $\mathrm{M}=3.60$ and female $\mathrm{M}=$ $3.61, \mathrm{SD}=.77, .65, \mathrm{P}$ value is .84 which is greater than $\alpha .01$ which means that there is a no significant difference between male and female self-perceived bodily/kinesthetic intelligence. Mean score of the male self-perceived interpersonal intelligence is $\mathrm{M}=3.27$ and female $\mathrm{M}=3.53, \mathrm{SD}=.69, .65, \mathrm{P}$ value is .00 which is less then than $\alpha$ 0.01 which means that there is a significant difference between male and female self-perceived interpersonal intelligence. Mean score of the male self-perceived intrapersonal intelligence is $\mathrm{M}=3.26$ and female $\mathrm{M}=3.57$, $\mathrm{SD}=.64, .55, \mathrm{P}$ value is .00 which is less than $\alpha 0.01$ which means that there is a significant difference between male and female self-perceived intrapersonal intelligence. Mean score of the male self-perceived naturalistic intelligence is $\mathrm{M}=3.23$ and female $\mathrm{M}=3.28, \mathrm{SD}=.71, .65, \mathrm{P}$ value is .37 which is greater than $\alpha 0.01$ which means that there is no significant difference between male and female self-perceived naturalistic intelligence.

Ishhq, Maqsood, Syed and Sardar (2010) investigated students' MI according to their preferences and how the students' MI differs in terms of gender at Elementary level. A sample of $20007^{\text {th }}$ class students aged above 12 years was drawn using stratified random sampling. Significant differences were observed in the mean scores of boys and girls for linguistic $(Z=1.97))$, body-kinesthetic $(Z=5.54)$, interpersonal $(Z=4.45)$ and naturalistic $(Z$ =3.89). Males were ahead of females in logical and bodily-kinesthetic while females took slight leads in linguistic and musical intelligence.

Lin (2009) examined gender and major differences in self-estimates of multiple intelligences within pre-service teachers at the national Changhua University of Education in Taiwan. The participants were 411 pre service teachers drawn from academic department. The result showed significant higher self-estimates for male were shown for mathematical mathematical-logical (mean $=39.65, \mathrm{t}$-value $=8.64 * * *)$ and bodily-kinesthetic $($ mean $=$ 42.51 , t-value $\left.=3.58^{* * *}\right)$ while females rated their Verbal-linguistic $\left(\right.$ mean $=36.72, \mathrm{t}$-value $\left.=-3.14^{* *}\right)$ and 
musical-rhythmic (mean $=38.90, \mathrm{t}$-value $=-2.77$ ) significantly higher. However, the study revealed that males do not generally estimate their intelligences higher compared to females.

Serin, Serin, Yavuz and Muhammedzade (2009) carried out a comparative study on factors affecting teaching styles and the multiple intelligence types of primary school teachers in Turkey and Cyprus. Simple random sampling was used to sample $140(57 \%)$ female and $105(42.9 \%)$ male primary teachers. The results showed that naturalistic intelligence changes in favour of male teachers $(t=2.220 ; p<0.0001)$ working in Cyprus (Lefkosa) and spatial intelligence changes in the favour of female teachers $(t=3,915 ; \mathrm{p}<0.001)$ in Turkey (Izmir).

Tirri and Nokelainen (2008) operationalized the nine MI scales by testing with an empirical sample of Finnish preadolescents $(n=183)$ and adults $(n=227)$. Results of the correlation analysis between gender and the MI scales showed that boys rated their logical-mathematical intelligence higher than girls, $\left(\mathrm{r}(183)=.39 ; \mathrm{p}<.01 ; \mathrm{r}^{2}\right.$ $=.15)$ Females tended to rate their linguistic abilities higher than males $\left(r(183)=-.18 ; p<.01 ; r^{2}=.03\right)$. In a similar study by Tirri and Komulainen (2002) among university students, male students were found to rate higher in logical-mathematical intelligence than females $\left(\mathrm{r}(256)=.27 ; \mathrm{p}<.001 ; \mathrm{r}^{2}=.07\right)$.

In a study to investigate the relationship between multiple intelligence and language proficiency among Iranian $\mathrm{PhD}$ candidates who participated in Shiraz university $\mathrm{PhD}$ entrance exam, Razmjoo (2008) found no significant difference among 119 males (mean $=311.60 ; \mathrm{SD}=37.16$ ) and 99 females (mean $=309.64 ; \mathrm{SD}=34.45$ ) participants' multiple intelligence in general and each type of intelligence in particular. However, the author concluded that the results were clearly suggestive due to lack of cooperation among students, lack of feasibility with respect to types of intelligences and influence of other variables like age and fields of study.

Naderi, Abdullah and Aizan (2008) investigated the difference between gender-role identity and intelligence among randomly sampled 153 undergraduate Iranian students (48 females and 105 males) in Malaysian Universities. The authors administered a Cattell Culture fair Intelligence Test and the results of the descriptive statistics focusing on average and t-test showed no significant difference between female and male students in relation to intelligence $(\mathrm{p}=0.443$; mean $=-1.932)$.

Loori (2005) utilized a sample of ninety international students of English as a Second Language. The author found that interpersonal intelligence ranked as the highest strength for both males (5.22) and females (4.73) however, logical-mathematical was the next highest strength for most males, whereas females' second highest intelligence preference was noted by spatial intelligence with a mean of 4.18. Johnson and White (2002) examined the MI strength among students of Criminal Justice at the University of West Florida. The participants were female $(n=110$ or $58.8 \%)$ and males $(n=77$ or $41.2 \%)$. The authors found significant verbal-linguistic intelligence results that indicated more strength for females $(10.9 \%)$ than males $(2.6 \%)$.

Göğebakan (2003) examined how students' multiple intelligences differ in terms of gender and results showed there was significant difference among the students' logical-mathematical intelligence mean according to gender(p<0,05; $X=3,21 \mathrm{sd}=1,99$ males' $X=4,29 \mathrm{sd}=2,25)$ students' logical-mathematical). Male and bodily kinesthetic intelligence mean scores $(\mathrm{p}<0,05: X=4,14 \mathrm{SD}=1,70)$ males' was $(X=4,72 \mathrm{SD}=1,54)$. There was significant difference among the students' means score of musical intelligence according to their gender $(\mathrm{p}<0,05)$. whereas the female students' musical intelligence mean (Females' musical intelligence score $X=$ $4,31 \mathrm{sd}=1$, was higher than male students' ( males' $X=2,92 \mathrm{sd}=1,57$ ). There was no significant difference in other types of intelligence.

The above studies are significant to this study as they revealed gender differences in types of intelligence among males and females which is consistent with the objective of this study. However, most of the studies like Cooijmans, (2011) focused mainly on logical mathematical, linguistic, spatial and bodily-kinesthetic and no other significant MI profiles like existentialist, intrapersonal and naturalistic. Studies by Tirri et al (2008) focused on preadolescents only hence was demographically limited. Studies that found out the levels of significance positive or negative like Loori (2005) focused on both males and females in non-African populations. Whereas Loori (2005) used Teele inventory and Naderi et al (2008) adopted Cattel Culture Fair Intelligence Test, the focus of this study is to examine if gender related difference on intelligence exist among Maseno University first-year undergraduate B.Ed students by multiple intelligence questionnaire since no previous researches has been done on the basis of these instruments. 


\subsection{Relationship between Types of Intelligence and Career Choice}

Armstrong (2009) suggested that the multiple domains of intellectual abilities have unique skills and occupational channels. According to Lenaghan (2000) as cited by Shiruffudin (2010), the interpersonal intelligence type is characterized by teaching, public speaking and leading. Information technology professionals also spare much thought about communication skills because they share their ideas visually and use flowcharts, blueprints, satellite images, and schematics. The old field leader of a sports team might not require a particular high I.Q especially if he or she is a talented athlete, experienced and knowledgeable of the sports (Reggio, Murphy, \& Pirozzolo, 2002).

Therefore a student with multiple intelligence will seek an academic programmes and courses congruent to their unique types (Armstrong, 2012; Kerka, 2012). For example the musically intelligent student will pursue course to horn their music skills like playing musical instruments, singing, recognizing tonal patterns, remembering melodies, composing music and understanding the structure and rhythm of music bodily-kinesthetic Intelligence student will pursue programmes such as physical education and fine arts whereas a student with logical mathematical intelligence use reason, logic and numbers, intense questioning and experimentations in sciences and mathematics and problem solving (Armstrong, 2006). Therefore, students training to be mathematicians or physicists, spend years sharpening their mathematical intelligence in a distinctive and logically relevant way. Young adults with visual-spatial intelligent skills may be fascinated with mazes, jigsaw puzzle building, reading, writing, understanding charts and graphs, a good sense of direction, sketching, painting, drawing, and creating visual metaphors and analogies, manipulating images, constructing, designing practical objects and interpreting visual images. Teacher-trainees and history students need 3-D modeling and visualization to recreate historic characters while geography, physics and chemistry teachers can make these subjects interesting when teaching concepts like gravitational force and pressure using 3-D animation (Kariuki, 2011). Naturalist intelligence include love for nature e.g. university botanical gardens, nature conservation and environment friendly courses like geography, zoology, botany. In a university academic environment, a student with existentialist and intrapersonal intelligent understanding, self-reasoning and one's role in a relationship with others through course like research, philosophy and psychology. (Wilson, 2012).

Table 1: Types of Intelligence and Sample Congruent Careers

Types of Intelligence Congruent Careers

Musical Musician, disk jockey, singer, composer, vocalist, music teacher, band director

Logical/ Mathematical Accountant, engineer, scientist, researchers, computer programmers, mathematicians, statistician, tax expert

Visual/ Spatial

Composers, conductors, music teacher, vocalists, musician, songwriter, music director, songwriter.

Bodily/ Kinesthetic

Verbal/Linguistic

Intrapersonal

Interpersonal

Naturalist

Existentialist
Athlete, choreographer, dancer, music director, firefighters, artisans, P.E tutors

Poet, journalist, public relations, writer, teacher, politician, lawyer, translator

Researchers, theorists, philosophers, psychologist

Salesperson, counselor, teacher, nurse, politician, business person

Biologist, farmer, botanist, meteorologist, veterinarian

Preacher, philosopher, star reader, astrologer

Source: Gardner( 2012); Shearer \& Luzzo, (2009)

http://www.Ipride.net/learningstyles.mi.htm

Yelkikala, Hacioglu, Kiray, Ezilmez, Ergul, Soylemezoglu, Cetin, Sonmez and Özturk (2014) examined the emotional Intelligence Characteristics of students studying at various faculties and colleges of universities 
accordingly, faculty of science and letters has the highest average of wellbeing (5.31) and School of Tourism Management has the lowest average (4.99). Faculty of Science and Letter also has the highest average (4.80) in terms of self-control whereas the Faculty of Fine Arts has the lowest average (4.43). The Faculty of Economics and Administrative Sciences (5.30) and the Faculty of Science \& Letters (5.30) have the highest averages in emotionality factor and the Faculty of Fine Arts has the lowest average (4.97). Faculty of Science \& Letters (5.24) and Fine Arts (5.22) have the highest averages in sociability factors whereas the Faculty of Economics and Administrative Sciences has the lowest average.

Hanafiye (2013) further scrutinized whether there is a significant relationship between a particular type of intelligence and success in grammar, listening and writing Results show that there is a low positive relationship between writing scores and musical intelligence $(\mathrm{r}=.182, \mathrm{p}<.033)$. The analysis also indicated some negative correlations. Bodily kinesthetic intelligence $(\mathrm{r}=-.166, \mathrm{P}<.049)$, intrapersonal intelligence $(\mathrm{r}=-.183, \mathrm{P}<.031)$, and spatial intelligence $(\mathrm{r}=-.172, \mathrm{p}<.042)$ had low negative correlations with students' grammar test scores.

Yamin (2013) conducted a study to investigate the types of mathematical thinking and its relationship with some variables to identify the relationships between the intelligences among 10th graders in Toolkarem governorate. The study sample consisted of (395) male and female students in the second semester 2012/2013. The results showed that the participants possess all the intelligences in varied levels. The interpersonal intelligence ranked first, while the spatial intelligence ranked last. The ratio of the students chose the scientific stream was $35 \%$ while the ratio of those who chose the humanity sciences was $65 \%$.

Ghazi et al (2011) investigated the relationship between students' self-perceived multiple intelligences and academic achievement of 714 male and female first year students enrolled in all government degree colleges in district Bannu in Pakistan. The study found significant correlation between self-perceived verbal/linguistic( $\mathrm{r}$ $=.26$; p.value $=.00$ at 0.01 level $)$, logical $/$ mathematical $(\mathrm{r}=.42 ; \mathrm{p}$. value $=.00$ at 0.01 level $)$ and students' academic achievement. However insignificant correlation was found between perceived musical intelligence and academic achievement $(\mathrm{r}=.05$; $\mathrm{p}$. value $=.14$ at 0.01 level $)$ and very weak correlation between bodily/kinesthetic intelligence and academic achievement. $(\mathrm{r}=.12$; p.value $=.04$ at 0.01 level). The finding by Ghazi et al (2011) is significant to this study because entry and progress in the degree choices under investigation are determined by academic achievement or paper and pencil tests scores.

Green, (2010) using a sample of twelve first quarter fashion students investigated the perceptions of usefulness using Holland Code theory and MI theory to determine their career niche in the fashion industry. Green (2010) found that all the student participants $(100 \%)$ were able to make a connection with their MI strengths. This means that the participants also selected careers which reflected their unique skills and abilities.

Alghazo et al (2009) investigated the types of multiple intelligences in social studies, Arabic and English books for the first three grades. The results of the study showed that most common type of intelligence in all the three books and grades was visual-spatial intelligence (Social studies $=33.4 \%$; Arabic $=46.14 \%$; English $=57.9 \%$ ). The least common type of intelligence is the physical (Social studies $=5.6 \%$; English $=3.2 \%$ ). The authors further used chi-square to find out the correlation between subject, type of intelligence and grade. The findings showed significant statistical differences in the percentages of MI which are found in the Social studies $\left(\chi^{2}=192.255 ; \mathrm{df}=8\right)$; Arabic language $\left(\chi^{2}=192.255 ; d f=8\right)$; and English language textbooks $\left(\chi^{2}=192.255 ; d f=\right.$ 8). The authors attributed the difference in distribution of the different multiple intelligences in the books to nature of the subject hence the varied percentages from one grade to another. The study by Alghazo et al (2009) is significant to this study because textbooks are the core of content analysis of training institutions and programmes hence reflect the types of intelligence.

Lin (2009) examined gender and major differences in self-estimates of multiple intelligences within 411 preservice teachers drawn from university departments. The Chinese literature department participants' selfestimated of verbal-linguistic intelligence $(\mathrm{F}-=3.04 ; \mathrm{p}<.001)$ were higher while Industrial education, mathematics, chemistry, physics departments participants' self-estimates of mathematical-logical intelligence (F $=13.66 ; \mathrm{p}<0$.001), were higher. The Art department participants' self-estimated visual-spatial intelligence $(\mathrm{F}=6.55, \mathrm{p}<.001)$ were higher. The physical education departments participants' self-estimates of bodily kinesthetic intelligence $(\mathrm{F}=3.3 .43 ; \mathrm{p}<.001)$ were higher. Participants from biology, geography departments' selfestimates of naturalistic intelligence $(\mathrm{F}=2.79 ; \mathrm{p}<.001)$ were higher compared to estimates from mathematics. There were no significant differences in musical-rhythmic, interpersonal, and intrapersonal intelligences among different departments. 
Serin, Serin, Yavuz and Muhammedzade (2009) examined the relationship between the teaching styles and the multiple intelligence types of primary school teachers in Izmir in Turkey and Lefkosa in Cyprus. Simple random sampling was used to draw a sample of $140(57 \%)$ female and $105(42.9 \%)$ male primary teachers. The results showed significant statistical differences between the following sub-scales; Verbal-linguistic $(\mathrm{t}=8.766 ; \mathrm{p}<$ 0.001), Logical-mathematical $(\mathrm{t}=11.021 ; \mathrm{p}<0.001)$, Spatial-visual $(\mathrm{t}=11,153 ; \mathrm{p}<0.001)$, Naturalistic $(\mathrm{t}=9.987$; $\mathrm{p}<0.001)$, Musical-rhythmic $(\mathrm{t}=6,033 ; \mathrm{p}<0.001)$, Bodily-kinesthetic $(\mathrm{t}=4.944 ; \mathrm{p}<0.001)$, Interpersonal $(\mathrm{t}=$ 4.802, $\mathrm{p}<0.001$ ) and Intrapersonal $(\mathrm{t}=4.133, \mathrm{p}<0.001)$. The authors attributed the differences to teachers working in Cyprus (Lefkosa) where the primary programmes have been prepared appropriate to the intelligence fields.

Further, Shearer (2006) explored the relationship between intrapersonal intelligence and university students' career decision making, retention and academic success. The sample consisted of 82 participants (49 females and 33 males). ANOVA showed the largest scale differences were for the Intrapersonal and Math/Logic scales which were both $12 \%$ points lower for the career exploration group. The lower academic skills scales reported were Linguistic and Logical-math (-7\%). According to Shearer (2006) this indicates that there is a moderately strong relationship between one's self-knowledge and degree of career clarity.

Matto, Berry-Edwards, Hutchinson, Bryant and Waldbilling (2006) conducted an exploratory study at Virginia Commonwealth University to determine faculty perceptions of the importance and effectiveness of MI when used for social work practice and education. Participants were 91 faculty members. The authors found that interpersonal (79.4\%) was considered important to the participants. In degree of effectiveness, both linguistics $(79.2 \%)$ and intrapersonal $(64.0 \%)$ were highly ranked, and the lowest degrees were indicated by spatial $(7.8 \%)$ and logical mathematic $(8.0 \%)$.

Students of Criminal Justice at the University of West Florida participated in a study to identify what career might best suit them, based on the strength of their multiple intelligences. The participants were female $(n=110$ or $58.8 \%)$ and males $(n=77$ or $41.2 \%)$. The MI results showed that $65 \%(n=115)$ of participants indicated strengths in intrapersonal intelligence, which Johnson and White (2002) contributed to the strength of being selfreflective and an awareness of one's internal state. Johnson and White (2002) concluded that criminal justice careers would be well served by persons with intrapersonal intelligence. According to Johnson and White, (2002) the strength in verbal-linguistic skills could be a benefit for the females who seek a career as an attorney; however, it could be considered a weakness for those who did not select it and are seeking a career in law enforcement. The Johnson and White (2002) study is significant because it can assist students in determining their Multiple Intelligences strengths and weaknesses and a self-identified occupation.

The literature reviewed above reveals no research studies done in Africa in general and Kenya in particular, to determine the relationship between type of intelligence and career choice in B.Ed programme by using MI model. The populations used by Razmjoo (2008) and Green (2010) were characterized by small sample sizes. Others studies focused on a specific populations like primary school teachers (Serin, et al 2009), American fashion students only (Green, 2010), PhD students (Razmjoo, 2008). Green (2010) focused on females only while this study will include both males and females undergraduate students. Some were focused on one type of intelligence like intrapersonal (Shearer, 2007). Most of the studies like Shearer (2009), (Green, 2010) did not address other types of intelligence like existentialist and naturalistic. Some studies used survey methods (Johnson \& White, 2002) and action research (Green, 2010) while this study will use exposto facto design to seek to determine the relationship between type of intelligence and career choice in the B.Ed programme among first-year B.Ed students of Maseno University, Kenya.

\section{Research Methodology}

Correlational and descriptive survey research designs were adopted for this study. According to Orodho, (2012), Fraenkel \& Wallen, (2008) in such a design, research inferences about relationships among variables are made systematically and empirically without direct control or manipulation of independent variables, because their manifestations have already occurred and because they are inherently non-manipulable. Ex-post facto design has been supported in educational research, which does not lead to experimental work (Fraenkel \& Wallen, 2008; Mugenda, 2011). The study also adopted descriptive survey method for this research. Such a research describes a situation, individual or object of study, to present evaluations in line with standards and to reveal relationships between phenomena (Mugenda, 2011; Cepni, 2009). According to Cherry (2013), descriptive surveys are fast, cheap, easy and more flexible. 


\subsection{Area of Study}

Maseno University in Kenya was conveniently selected as the study area. The choice of Maseno University was influenced by the typical snowballing nature of B.Ed training programmes in public universities in Kenya. In addition Maseno University has a long history of offering unique courses like Fine art and Music, which according to Holland fall distinctly under artistic fields. Maseno University was purposively selected for the study because it also offers a five undergraduate B.Ed programmes with a unique information technology component not offered in any other public universities and subject options hence high on spectrum of types of intelligence.

\subsection{Study Population}

The target population in this study included all the 490 (353 males and 137 females) first-year undergraduate students at the Maseno University main campus during the 2011/2012 academic year. First-year B.Ed. student were selected for this study because it forms the one bipolar end of university degree choice career turbulence of entry-change verses exit-career change. First-year students have also not stabilized in the degree program and face unexpected career turbulence hence are likely to change or drop out. Universities also tend to periodically restructure their programmes, courses and training designs normally tailored for the needs incoming first year students. First-year students may be unaware of these types of intelligence which apparently remain untapped or assumed in Maseno university B.Ed. programmes training and research. Lastly, B.Ed. students are a representative in all disciplines be it sciences, humanities or languages.

\subsection{Sample Size and Sampling Technique}

First, a sample size of 220 B.Ed students was obtained by using a formula developed by Israel (2013) cited by Cherry (2103). The sample size $(n=220)$ is acceptable as Gay, Mills and Aurasian (2007) cited by Cherry (2103) recommends a minimum sample size of 30 for correlation study in establishing the existence or nonexistence of a relationship. Proportional stratified sampling was then used to ensure that students from the five cohorts under the School of Education are adequately selected and represented in the sample in proportion to their number in the population hence maximized the likelihood of representativeness (Cherry, 2013),). The sample size is presented in Table 2;

Table 2: Sample Size

Programme JAB SPECIAL TOTAL SAMPLE SIZE

\begin{tabular}{lllllllll} 
& M & F & T & M & F & T & & \\
\cline { 2 - 5 } B.Ed - Arts & 162 & 42 & $\mathbf{2 0 4}$ & 37 & 24 & $\mathbf{6 1}$ & 265 & $265 / 490 \times 220=119$ \\
B.Ed -Science & 89 & 23 & $\mathbf{1 1 2}$ & 11 & 4 & $\mathbf{1 7}$ & 129 & $129 / 490 \times 220=58$ \\
B.Ed -ECDE & 17 & 13 & $\mathbf{3 0}$ & 0 & 0 & $\mathbf{0}$ & 26 & $26 / 490 \times 220=12$ \\
B.Ed -Special & 17 & 8 & $\mathbf{2 6}$ & 9 & 7 & $\mathbf{1 6}$ & 42 & $42 / 490 \times 220=19$ \\
B.Ed -French & 4 & 6 & $\mathbf{1 0}$ & 7 & 10 & $\mathbf{1 7}$ & 27 & $27 / 490 \times 220=12$ \\
\hline TOTAL & $\mathbf{2 8 9}$ & $\mathbf{9 2}$ & $\mathbf{3 8 1}$ & $\mathbf{6 4}$ & $\mathbf{4 5}$ & $\mathbf{1 0 9}$ & $\mathbf{4 9 0}$ & $\mathbf{2 2 0}$
\end{tabular}

Simple stratified random sampling technique was then be used to select respondents from each cohort to take part in the research. The starting point or respondent was determined randomly and samples drawn until the desired sample size was attained. This was also because it was practically impossible to get all the respondents in a single assembly. The choice of the number of respondents in each cohort sample was based on gender hence by quota sampling, the higher the number in the cohort the higher the number selected relative to the cohort sample size.

\subsection{Instrumentation}

This study employed a modified types of intelligence questionnaire based on Howard Gardner's Multiple Intelligence profiles. In this study, a Questionnaire: based on a five-level Likert scale (Describe me completely =1; Describe me fairly well $=2$; Unsure $=3$,Doesn't describe me very well $=4$ and Doesn't describe me at $a l l=5$ ) was used to gather the qualitative data. The items were not serialized to minimize on response biasness and spontaneity. The questionnaires were also anonymous and confidential. 


\subsection{Reliability and Validity of Instruments}

For the reliability and to remove language ambiguity the questionnaire was personally distributed among forty nine $(10 \%)$ of the study population) subjects as a pilot run. The pilot study was conducted among randomly selected 49 first-year undergraduate students in the B.Ed programmes of Maseno University. Pearson Product Moment correlation was used to determine reliability at alpha level 0.05 . The resulting value obtained was a reliability index of 0.84 . Test-retest reliabilities for most MIDAS across multiple samples range between 0.78 and 0.89 with a mean of 0.86 (Shearer, 2007) This means that the instruments were reliable enough to be used answer the research questions in the actual study.

To ensure face and content validity of the questionnaires and interview schedule, the research instruments were screened for content and language appropriateness by three psychometric experts from the Department of Educational Psychology, Maseno University and their input included in the final draft of the instruments.

\subsection{Procedure for Data Collection}

A research permit was obtained from Maseno University Ethics Review Committee (MUERC) to facilitate conducting of the study within Maseno University. The researcher got introduced to various lecturers in-charge of various course units. The researcher made appointments with the lecturers to administer the questionnaires during a lecture session.

Data was collected cross-sectionally from each cohort sample on a weekly timeframe in the first quarter of the second semester over a period of one month. This data was collected during a regular lecture session and students who were present took part voluntarily. Subjects who were not willing to complete the questionnaire were not compelled to do so. The questionnaires were administered by visiting the B.Ed programme's two-hour common unit specified lectures and after explaining the purpose of the study, confirming voluntary participation and assuring all respondents of confidentiality, distributed the questionnaire to the respondents in the lecture hall. The students were given few minutes to fill and return the questionnaire and took an average of 30-35 minutes to complete the questionnaire. This ensured immediate high rate of return and low cost factor. On-the-spot administration of questionnaire also ensured non-interference from other variables like response assistance and gave the researcher an opportunity to explain the study.

\subsection{Methods of Data Analysis}

The qualitative and quantitative data to be collected from the study was analyzed at two levels. The raw data generated using the questionnaire was coded and entered into a Statistical Package for Social Sciences (SPSS) computer program. The data was analyzed according to the objectives posted for the study.

First, descriptive data from closed ended items in the questionnaire like gender, study category, career choice, intelligence type, were subjected to computation of descriptive statistics such as frequency counts and percentages; and central tendency measure of mode. A type of intelligence among first year B.Ed students was computed using percentages. Similarly the significant difference in gender and types of intelligence was established using mean gender differences across types of intelligence. The SPSS program was used for this analysis.

Secondly, cross tabulation with Chi-square test $\left(\chi^{2}\right)$ was employed to examine the presence of any relationship between types of intelligence and gender, types of intelligence and career choice. As a non-parametric test, chisquare is used to determine if the categorical data in the objectives shows dependency or the two classifications are independent (Fraenkel \& Wallen, 2008). This was further subjected to Likelihood ratio test to determine the degree or level of the relationships between two variables. Chi-square was selected because it makes no assumption such as normality about distribution of population. The two analytical techniques reinforced each other and enabled the researcher to explain findings obtained from the questionnaire. The MIDAS Professional Manual (Shearer, 2007) was utilized to interpret the results and categorize each respondent into an intelligence type(s). The MIDAS ranking scale by Shearer (2007) scores range from $0-100 \%(* 80-100=$ Very High: *60 $79 \%=$ High: $40-59 \%=$ Moderate $: 20-39=$ Low: $* 0-19=$ very Low).

\subsection{Logistical and Ethical considerations.}

The researcher obtained the required licenses and letters of authorization to carry out the study from Maseno University. The lecturers were contacted to allow the researcher to gather data during their lecture sessions. Volunteer research assistants helped the researcher to collect code and analyze the data. Students who took part in this study did so voluntarily and were also free to withdraw from the study if they so wished. The researcher first briefed the subjects on the purpose of the study, and assured all respondents of confidentiality. To ensure 
confidentiality was maintained, the researcher assured the participants that the purpose for data collected was purely for this study and the data will not be used for any other purpose.

\section{Results and Discussions}

The chapter presents results and discussions of the findings of the study. The findings were presented according to the objectives of the study.

\subsection{Types of Intelligence among First-Year Undergraduate Students In The B.Ed Programmes Of Maseno} University.

To find an answer to this problem; what different intelligences do first-year B.Ed students have? The students' percentages were calculated. The results showed that students scored very high in interpersonal intelligence (90.9\%), verbal-linguistic intelligence $(90.5 \%)$, logical-mathematical intelligence $(88.2 \%)$, bodily-kinesthetic $(85.9 \%)$, and naturalistic intelligence $(82.7 \%)$. However the students scored high on musical-rhythmic intelligence $(79.1 \%)$ visual-spatial intelligence $(75.5 \%)$, intrapersonal intelligence $(75.5 \%)$ and existentialist intelligence $(78.2 \%)$ hence these were considerably regarded less common intelligences. The types of intelligences (frequency counts, percentages and rank) are presented in Table 3;

Table 3: Types of Intelligence among First -Year B.Ed Students

\begin{tabular}{lrrr} 
Type of Intelligence & Number & Percentage & Rank \\
\hline Interpersonal & 200 & 90.9 & 1 \\
Verbal-Linguistics & 199 & 90.5 & 2 \\
Logical-mathematics & 194 & 88.2 & 3 \\
Bodily-Kinesthetic & 189 & 85.9 & 4 \\
Naturalistic & 182 & 82.7 & 5 \\
Musical-Rhythmic & 174 & 79.1 & 6 \\
Existentialist & 172 & 78.2 & 7 \\
Intrapersonal & 166 & 75.5 & 8 \\
Visual-Spatial & 166 & 75.5 & 8 \\
\hline
\end{tabular}

The presence of individuals under the high level in certain intelligence domains (existentialist, visual-spatial and intrapersonal) could be attributed to the limited of use of abilities specific to that domain. The high scores in the visual-spatial intelligence $(75.5 \%)$ are similar to results by previous researchers in identifying multiple intelligence domains (Hanifey, 2013). But, as for the visual-spatial intelligence which occupied the last rank at $75.5 \%$, this result can be attributed to the low focus on aspects related to visual-spatial intelligence such as visual imagination, visual symbols, colored slides, mental images, spatial reasoning, tables, paintings, drawings, and illustrations.

These findings are similar to the study by Mustafa, Jado and Onoz, (2014) who found linguistic intelligence ranked first with mean scores of (9.97) and SD of (3.02), then came the intrapersonal intelligence with mean scores of (8.34) and a SD of (2.29), while the visual-spatial intelligence ranks last with mean scores of (6.98) and a SD of (3.68). The high scores on verbal-linguistic $(90.5 \%)$ in the current study could be attributed to the focus of the educational systems in Kenya either in universities on developing linguistic intelligence among students through using teaching strategies based on exposition, lecturing, questioning, and dialogue as well as using verbal and written language in different types of assessment and evaluation. As for as the interpersonal intelligence which ranked first; this result can be attributed to the nature of students at the university level, where they enjoy higher levels of social freedom, psychological and emotional stability, and become more able to identify their identities including a spirit of comradeship.

The results of this study are also in harmony with the findings of For example, Eid and Alizh, (2004) assert that a person can have extra ordinary but low musical intelligence. Mustafa, Jado and Onoz (2014) Mahasneh (2013), Al-Sabbbah(2011), Al-Alwan (2008), Yamin (2013), Gogebanakan (2003), Yamin, (2013) and Khataybeh \& AlBdor 2006) and Net, Ruiz, \& Turnham (2008) asserting that a person may have all the multiple intelligences or some of them with varying degrees for example, Ozdemir, Gunesy and Tekkaya (2006) found that adolescents in Turkey ranked highly in logical-mathematical intelligence, however linguistic intelligence and interpersonal while musical intelligence was least common. In a study by Yamin (2013) and Matto et al (2006) interpersonal intelligence ranked first, while the spatial intelligence ranked last. However, the findings are in contrast with the studies carried out by Golam (2011), Matto (2006) and Sharriffudin (2010) and Matto et al (2006) which ranked intrapersonal highly $(64.0 \%)$ and the lowest degrees were indicated by spatial $(7.8 \%)$ and logical mathematic 
$(8.0 \%)$. , interpersonal $(29.6 \%)$, naturalistic $(29.6 \%)$. These studies support the findings this study that Maseno university undergraduate students possess all the domains of multiple intelligences in varying high degrees.

The researcher further examined the distribution of types of intelligence within the B.Ed programmes. The results of the study showing distribution of types of intelligence within the B.Ed programmes as presented in table 4;

Table 4: Distribution of Types of Intelligence within B.Ed Degree Programmes

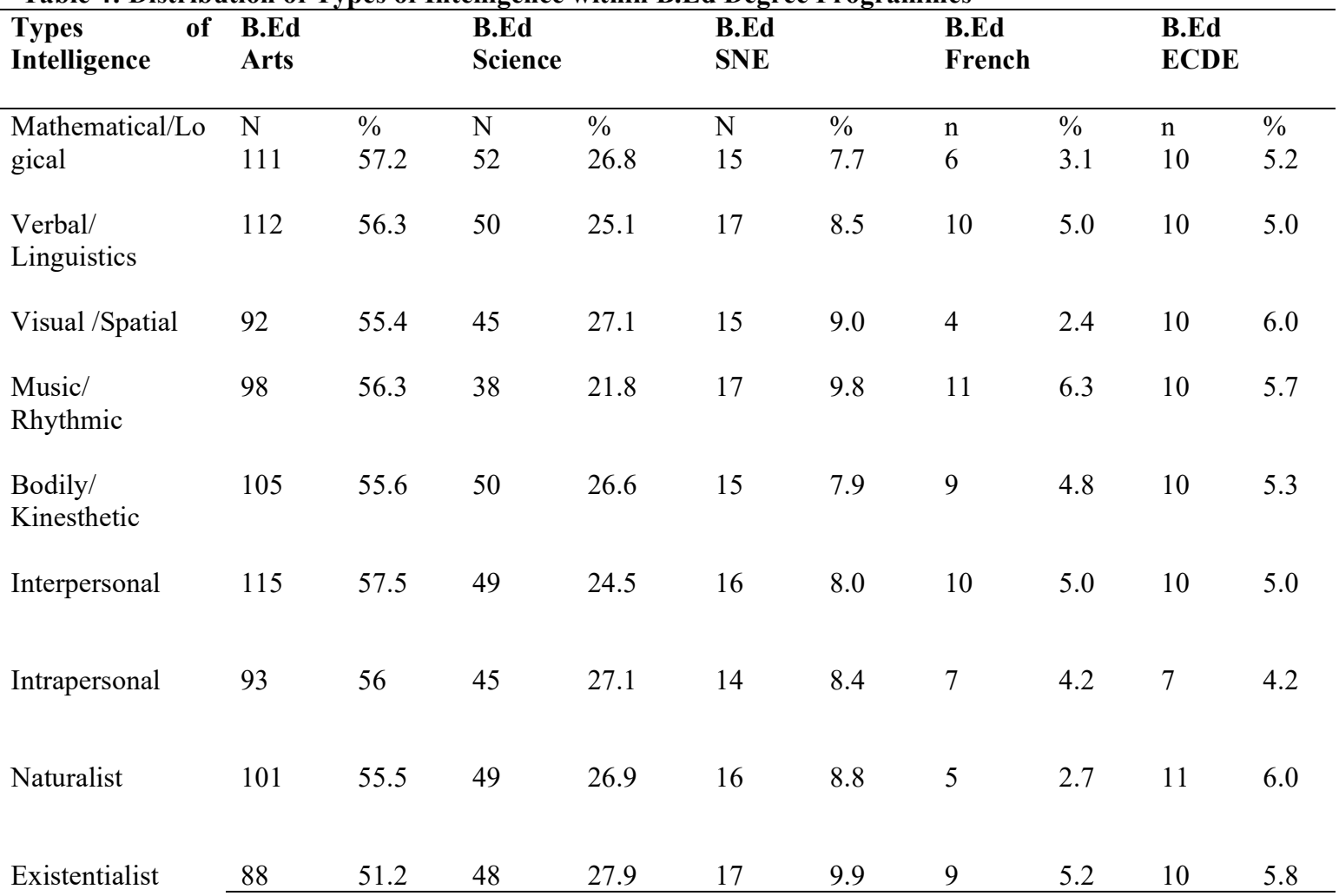

Table (4) show that the most common types of intelligence in the B.Ed (arts ) is interpersonal intelligence $(\mathrm{n}=115 ; 57.5 \%)$ and logical mathematical $(\mathrm{n}=111: 57.2 \%)$. Whereas B.Ed arts recorded at least $50 \%$ in all types of intelligence, the least type of intelligence is existentialist $(n=88 ; 51.2 \%)$. In B.Ed science, the least type of intelligence is the music/rhythmic $(\mathrm{n}=38 ; 21.8 \%)$. However, within B.Ed science logical-mathematical recorded the high number of respondents $(n=52 ; 26.8 \%)$. The results can be attribute to the nature of the scientific departments which focus on scientific concepts, methodologies, activities and skills through a wide range of tools based on scientific thinking, reasoning, evidence, and experiments. Results also show that in B.Ed-SNE, the most common types of intelligence are verbal-linguistic $(n=17 ; 8.5 \%)$; music-rhythmic $(n=17 ; 9.8 \%)$ and existentialist $(n=17 ; 9.9 \%)$. However, intrapersonal intelligence recorded the least number of respondents $(n=14$; $8.4 \%$ ) within the B.Ed-SNE. The type of intelligence with highest number of respondent within B.Ed -French is musical-rhythmic $(n=11 ; 6.3 \%)$ while the least is visual-spatial $(n=4 ; 2.4 \%)$. B.Ed-French share with B.Ed-Arts similar dominant types of intelligence especially verbal linguistic intelligence, music-rhythmic and interpersonal intelligence. This can be due to the two programmes share almost common units of instructions especially in the linguistics department, pure arts, humanities which focus on the methodologies, activities, and skills that develop the linguistic, interpersonal, musical intelligences through concentrating on certain strategies such as discussion, dialogue, verbal and written expression, debate, artistic and literary taste. These results imply that types of intelligences are highly distributed across the B.Ed programmes. However the large differences in percentages reflect the large sample size differences from each programme and should not be misinterpreted by the reader since this study was done with large groups especially in the B.Ed Arts and B.Ed-Science and this may have obscured important individual and subgroup differences for groups with low enrolments like B.EdFrench, B.Ed-ECDE. The findings of this study are similar to the study conducted by Yamin (2013) who 
reported that the ratio of the students chose the scientific stream was $35 \%$ while the ratio of those who chose the humanity sciences was $65 \%$.

4.2 Gender Difference In The Types Of Intelligence Among The First-Year Undergraduate Students In The B.Ed Programmes Of Maseno University.

To answer the second question" How do male and female first year students differ in types of intelligence?', the frequencies counts and percentages of the study sample on the nine intelligence abilities were calculated as shown in table 5;

Table 5: Gender Difference in Types of Intelligence

\begin{tabular}{lrrrrrr}
\hline Types of Intelligence & Males & \multicolumn{3}{c}{$\begin{array}{c}\text { Responses by Gender } \\
\text { Females }\end{array}$} & Difference \\
& & & & \% & N & \% \\
\hline Mathematical/Logical & 114 & 58.8 & 80 & 41.2 & 34 & 17.6 \\
Verbal/Linguistics & 117 & 58.8 & 82 & 41.2 & 35 & 17.6 \\
Spatial/Visual & 100 & 60.2 & 66 & 39.8 & 34 & 20.4 \\
Music/Rhythmic & 108 & 62.1 & 66 & 37.9 & 42 & 24.3 \\
Bodily/Kinesthetic & 105 & 55.6 & 84 & 44.4 & 21 & 11.2 \\
Interpersonal & 117 & 58.5 & 83 & 41.5 & 34 & 17 \\
Intrapersonal & 98 & 59 & 68 & 41 & 30 & 18 \\
Naturalist & 116 & 63.7 & 66 & 36.3 & 50 & 27.4 \\
Existentialist & 101 & 58.7 & 71 & 41.3 & 30 & 17.4 \\
\hline
\end{tabular}

Males scored higher (over 50\%) in all the types of intelligence. In verbal/linguistic intelligence males $(58.8 \%)$ and female $(41.2 \%)$, while in logical/mathematical intelligence male scored $(58.8 \%)$ and female (41.2\%). Mean score of the male self-perceived visual/spatial intelligence is $(60.2 \%)$ and female $(39.8 \%)$ which means that there is a significant difference between male and female self-perceived visual/spatial intelligence in favour of males. Mean score of the male musical intelligence is $(62.1 \%)$ and female $(37.9 \%)$. The results show no significant difference between male and female self-perceived bodily/kinesthetic intelligence. These results confirm the findings of many studies Afanah and Al-Khazendar (2003), Gogebanakan ( 2003), Net, Ruiz, \& Turnham (2008), Al-Alwan (2008), Nofal and Al-Heeleh (2008), while these results disagree with other studies such as Golam (2011) and (Khataybeh \& Al-Bdor, 2006).

The researcher further subjected the scores on relationship between gender and types of intelligence to a chisquare test. Chi-square results are presented in table 6.

Table 6: Chi-square results for relationship between Types of Intelligence and Gender

\begin{tabular}{|c|c|c|c|c|}
\hline Types of Intelligence & Gender & Value & df & $\begin{array}{r}\text { Asymp. Sig. (2- } \\
\text { sided) }\end{array}$ \\
\hline Mathematical/Logical & $\begin{array}{l}\mathrm{M} \\
\mathrm{F}\end{array}$ & $60.363^{a}$ & 35 & .005 \\
\hline Verbal/Linguistics & $\begin{array}{l}\mathrm{M} \\
\mathrm{F}\end{array}$ & $64.768^{a}$ & 38 & .004 \\
\hline Visual/Spatial & $\begin{array}{l}\mathrm{M} \\
\mathrm{F}\end{array}$ & $46.300^{\mathrm{a}}$ & 33 & .062 \\
\hline Music/Rhythmic & $\begin{array}{l}\mathrm{M} \\
\mathrm{F}\end{array}$ & $59.093^{\mathrm{a}}$ & 37 & .012 \\
\hline Bodily/Kinesthetic & $\begin{array}{l}\mathrm{M} \\
\mathrm{F}\end{array}$ & $53.100^{\mathrm{a}}$ & 33 & .015 \\
\hline Interpersonal & $\begin{array}{l}\mathrm{M} \\
\mathrm{F}\end{array}$ & $57.433^{\mathrm{a}}$ & 47 & .142 \\
\hline Intrapersonal & $\begin{array}{l}\mathrm{M} \\
\mathrm{F}\end{array}$ & $19.771^{\mathrm{a}}$ & 19 & .408 \\
\hline Naturalist & $\begin{array}{l}\mathrm{M} \\
\mathrm{F}\end{array}$ & $41.928^{\mathrm{a}}$ & 34 & .165 \\
\hline Existentialist & $\begin{array}{l}\mathrm{M} \\
\mathrm{F}\end{array}$ & $84.285^{\mathrm{a}}$ & 34 & .000 \\
\hline
\end{tabular}


The Chi-square results in table 7 indicate that there is a significant difference between male and female in logical/mathematical ( $d f 35, p=0.005)$, verbal/linguistic $(d f 38, p=0.004)$ and existentialist $(d f 34, p=0.000)$, music-rhythmic ( $d f 37, p=0.012)$ and bodily-kinesthetic ( $d f 33, p=0.015)$ intelligence in favour of males. Results show no significant difference in visual-spatial ( $d f 33, p=0.06)$, interpersonal $(d f 47, p=0.142$, ), intrapersonal $(d f 19, p=0.408)$ and naturalistic ( $d f 34, p=0.165)$. The sex moderator which shows a few differences on the level of types of intelligence is not unusual. The minor gender differences may be a reflection of the greatly different sample sizes. These minor differences correspond to findings by several researchers who found gender differences on the level of types of intelligence. For example, Mustafa, et al, (2014) reported no statistically significant differences $(\mathrm{p}=0.05)$ on the intrapersonal intelligence while there are significant differences $(\mathrm{p}=0.05)$ between the mean attributed to the gender on the logical-mathematical, visual-spatial, and bodily-kinesthetic, and naturalistic intelligences, in favor of males. Hanafiye (2013) revealed a significant difference between males and females only in linguistic intelligence $(\mathrm{p}<.02)$. Tirri and Komulainen $(2008)$ found male students to rate higher in logical-mathematical intelligence than females $\left(\mathrm{r}(256)=.27 ; \mathrm{p}<.001 ; \mathrm{r}^{2}=.07\right)$. Razmjoo (2008) found no significant difference among 119 males (mean $=311.60 ; \mathrm{SD}=37.16$ ) and 99 females (mean $=309.64 ; \mathrm{SD}=34.45)$ participants' multiple intelligence in general and each type of intelligence in particular. However, the findings is at variance with other research findings, for example, the researches on types of intelligence considering gender variable conducted by Mustafa, et al, (2014) found significant differences $(\mathrm{p}=0.05)$ in favor of females on the linguistic, interpersonal, and musical intelligences, Shahzada, et al (2011) reported a significant difference between male and female verbal/linguistic intelligence in favour of females (male, $\mathrm{M}=3.08$ and female $\mathrm{M}=3.41, \mathrm{SD}=.75, .65, \mathrm{P}$ value is .00 ) and significant difference between male and female in visual/spatial intelligence in favour of females (male $\mathrm{M}=3.05$ and female $\mathrm{M}=3.24, \mathrm{SD}=.73$, .63, $\mathrm{P}$ value is .00) and Tirri and Nokelainen (2008) Females tended to rate their linguistic abilities higher than males $\left(\mathrm{r}(183)=-.18 ; \mathrm{p}<.01 ; \mathrm{r}^{2}=.03\right)$. This study therefore supports the several studies which have reported gender differences in types of intelligence with some supporting females and others support males.

\subsection{The Degree of Relationship Between Types Of Intelligence And Career Choice Among First-Year Undergraduate Students In The B.Ed Programmes.}

The researcher employed Pearson chi square and Likelihood ratio test to determine the degree of relationship between types of intelligence and career choice in the Bachelor of Education degree programmes. The results of the of chi-square and likelihood ratio test are presented in table 7 ;

Results the chi square test show that there is a significant relationship $(r=.182, p<.000)$. between types of intelligence and B.Ed programmes. The difference in the distribution of types of intelligence in the B.Ed programmes is linked to the nature of the subjects offered in the programmes. The results are in harmony with the findings by Serin et al (2009) who reported significant statistical differences between the following subscales; Verbal-linguistic $(\mathrm{t}=8.766 ; \mathrm{p}<0.001)$, Logical-mathematical $(\mathrm{t}=11.021 ; \mathrm{p}<0.001)$, Spatial-visual $(\mathrm{t}=$ $11,153 ; \mathrm{p}<0.001)$, Naturalistic $(\mathrm{t}=9.987 ; \mathrm{p}<0.001)$, Musical-rhythmic $(\mathrm{t}=6,033 ; \mathrm{p}<0.001)$, Bodily-kinesthetic $(\mathrm{t}=4.944 ; \mathrm{p}<0.001)$, Interpersonal $(\mathrm{t}=4.802, \mathrm{p}<0.001)$ and Intrapersonal $(\mathrm{t}=4.133, \mathrm{p}<0.001)$. The authors attributed the differences to teachers working in Cyprus (Lefkosa) where the primary programmes have been prepared appropriate to the intelligence fields. However, the findings differ from the findings by Lin (2009) who reported no significant differences in musical-rhythmic, interpersonal, and intrapersonal intelligences among different departments. These results of the likelihood ratio test presented in table 14 above show very strong or high $(\mathrm{p}<.000)$ degree of relationship between types of intelligence and career choice degree in the B.Ed programmes. This high relationship can be attributed to the predetermined criteria of subject mean scores and combinations, training strategies and expected course outcomes specific to each degree programmes. These results imply that students seek to be enrolled in a degree program where their interests will be fulfilled as they develop competencies. 
Table 7: Results of Chi-Square and Likelihood Ratio Test On Relationship Between Types of Intelligence and Career Choice

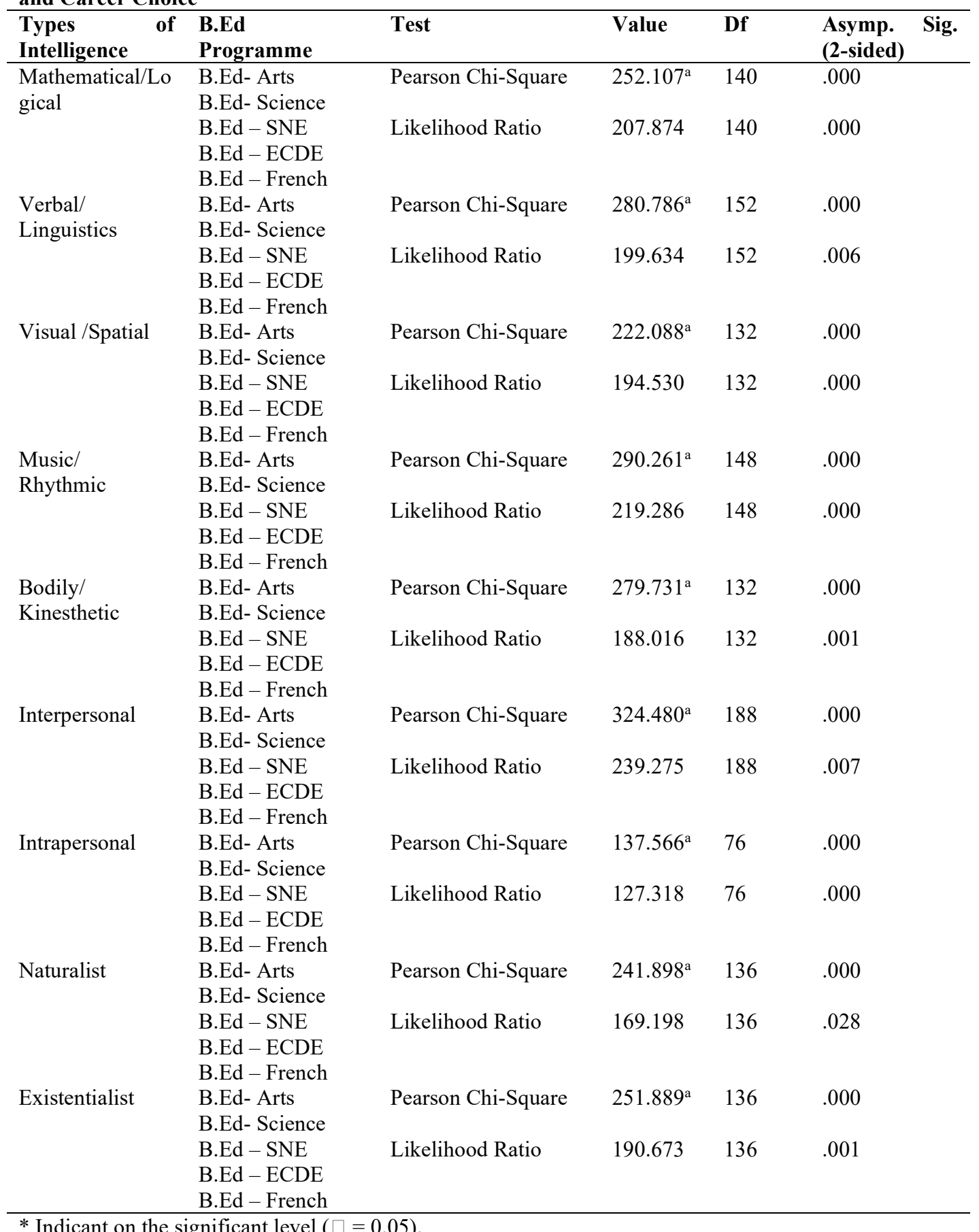

\section{Conclusion}

This chapter presents a summary of the findings, conclusions and recommendations of the study.

5.1 Types of intelligence among first-year undergraduate students in the Bachelor of Education degree programmes of Maseno University.

The results showed that first-year students scored very high in interpersonal intelligence (90.9\%), verballinguistic intelligence $(90.5 \%)$, logical-mathematical intelligence $(88.2 \%)$, bodily-kinesthetic $(85.9 \%)$, and naturalistic intelligence $(82.7 \%)$. However the students scored high on musical-rhythmic intelligence $(79.1 \%)$ 
visual-spatial intelligence $(75.5 \%)$, intrapersonal intelligence $(75.5 \%)$ and existentialist intelligence $(78.2 \%)$ hence these were considerably regarded less common intelligences.

5.2. Gender difference in the types of intelligence among the first-year undergraduate students in the Bachelor of Education degree programmes of Maseno University.

The study results clearly indicate significant difference between male and female in logical/mathematical $(d f 35$, $p=0.005)$, verbal/linguistic $(d f 38, p=0.004)$ and existentialist $(d f 34, p=0.000)$, music-rhythmic $(d f 37, p=$ $0.012)$ and bodily-kinesthetic $(d f 33, p=0.015)$ intelligence in favour of males. Males scored higher (over $50 \%)$ in all the types of intelligence. Results show no significant difference in visual-spatial ( $d f 33, p=0.06$ ), interpersonal ( $d f$ 47, $p=0.142$,), intrapersonal ( $d f$ 19, $p=0.408$ ) and naturalistic $(d f 34, p=0.165)$ intelligence domains. The minor gender difference between male and female may be a reflection of the greatly different sample sizes within programmes.

5.3 Degree of relationship between types of intelligence and career choice among first-year undergraduate students in the Bachelor of Education degree programmes.

Results the chi square test show that there is a significant relationship $(\mathrm{r}=.182, \mathrm{p}<.000)$ between types of intelligence and B.Ed programmes which indicates that there are differences in percentages of multiple intelligence found in the B.Ed programmes. These results of the likelihood ratio test show very strong or high $(p<.000)$ degree of relationship between types of intelligence and career choice degree in the B.Ed programmes.

\subsection{Recommendations}

The above implications led to the following recommendations based on the objectives of the study to Universities, policy makers and researchers.

\subsubsection{General Recommendation}

i. Students should seek career choices in universities that they possess liking, ability or inmate passion for.

\subsubsection{Recommendation to universities}

i. The university should ensure that students are placed in corresponding academic discipline where their unique abilities will be nurtured.

ii. The School of Education at Maseno University is encouraged to design their courses and teaching methodologies in accordance with the dominant multiple intelligences among their students. In particular, the university is encouraged to give more attention to the visual-spatial intelligence.

\subsubsection{Recommendations for the Policy makers}

iii. It is beneficial the Ministry of Education in Kenya to examine the implication of these MI career model using a large population to inform career guidance practice. This will be in support of the numerous attempts made by Ministry of Education in Kenya seeking to institutionalize the provision of career guidance in learning institutions.

\subsubsection{Recommendations for Further Research}

i. In the present study, data on multiple intelligences were collected using questionnaire. The problem with these instruments is that students' choices are limited .Further studies based on other data collection methods can be employed like online SDS tools and surreptitious observations.

ii. The study recommends that the need to investigate factors at the university environment which influences the development of female and male intelligences.

iii. Since the findings of this study came from one large public university whose it's recommended that the study be replicated with a private university

\section{REFERENCES}

Acosta, M. (2012). Multiple Intelligence Action Research. . Retrieved from http:/www.the Writting tutor.biz/articles/MI-intro-roblem.phpon 25/1/2012 .

Academic D. (2012). Maseno University Academic Programmes. Retrieved from www.masenouniversity.ac.keon 27/10/2012.

Allen, J. \& Robbins, S. (2010). Effects of interest-major congruence, motivation, and Academic performance on timely degree attainment. Journal of Counseling Psychology, 57, 23-35. 
Alghazo, K., Obeidat, H., Al-Trawneh, M. \& Alshraideh, M. (2009). Types of Multiple intelligences in Social Studies, Arabic and English Language Textbooks for First Three Grades. European Journal of Social Sciences Vol 12 No.1.

Al-Sabbah, S., Al-Sabbah, S. \& Abod, F. (2011). The Implications of MI Theory and IDAS Scale for Educators and Students in Jordanian Schools. International Journal of Innovation, Management and Technology, Vol.2, No.2, April 2011.

Al-Ahdal, A. Z. (2009). The Effectiveness of Activities and Methodologies of Instruction Based On Multiple Intelligences Theory In Improving Geography Achievement And Learning Retention Of 1st Secondary Female Students In Jeddah Governorate. The Journal of Um-Alqura For Educational And Psychological Sciences, Vol. 1 (1), 192-242.

Al-Alwan, A. F. (2008). Identifying The Intelligence Preferences Among 4th And 8th Graders In Accordance with Multiple Intelligence Theory, Dirasat Journal, University of Jordan, Educational Sciences, Vol. 37 (2), 454-474.

Al-Aslani, R. M. (2010). The Effectiveness Of A Remedial Strategy In Light Of Multiple Intelligences On Developing Geometry Achievement And Attitudes Towards Geometry Among 2nd Preparatory Slow Learners In Jeddah Governorate. Unpublished Ph. D Thesis, Females Faculty of Education, Jeddah, Saudi Arabia.

Armstrong, T. (2012). What are the Types of Multiple Intelligence? Retrieved from http://www.Idpride.net/learningstyles.MI.htm on 25/10/2012.

Armstrong, T. (2006). Multiple intelligences strategies for building reading and math skills. Alexandria, VA: Association for Supervision and Curriculum Development.

Arudo, T.O. (2008). Peer Counseling experiences among selected Kenyan Secondary Schools. KAPA Conference, $2^{\text {nd }}-4^{\text {th }}$ September.

Cherry, K. (2013).Psychology Research with Correlational Studies. Retrieved from http://psychology.about.com/od/researchmethods/a/correlational.htm on 22/3/2013.

Cohen, H. (2012). What is Intelligence and How is it Measured? Retrieved http://www.aboutintelligence.co.uk/what-intelligence.html. on 10/6/2012.

Cooijmans, P. (2013). Sex Differences in Intelligence. Retrieved www.Paulcooijmans. com/intelligence on $7 / 3 / 2013$.

Eid, R. \& Alizh, I. (2004).Applying MI Theory in Teacher training Programmes. Resalt

Freankel, H.R., \& Wallen, N.E (2008). How To Design And Evaluate Research In Education. Mcgraw-Hill. Higher Education. New York.

Gallup Africa International (2012). The Status of Higher Education in Kenya. www.gallupafrica.com retrieved $3 / 9 / 2012$

Gardner, H. (2012). The Nine Types of Intelligences .Retrieved from http://skyview.vansd.org/ischimdt/Projects/The\%20Nine\%20Types\%2 on 20/10/2012.

Gardner, H. (2006). Development and Education of the Mind. The Selected Works of Howard Gardner. London: Routledge.

Gardner, H. (2003). Multiple Intelligences after 20 Years. A Paper Presented at the American Educational Research Association, Chicago: Illinois, April 21, 2003.

Gardner, H. (2000). Intelligence Reframed: Multiple Intelligence for the $21^{\text {St }}$ Century. New York: Basic.

Gardner, H. (1983). Frames of Mind: The Theory of Multiple Intelligences. New York: Basic

Ghazi, R.S., Shahzada, G., Gilani, U. S., Shabbir, N.M., \& Rashid, M. (2011). Relationship Between Students' Self Perceived Multiple Intelligence and their Academic Achievement. International Journal of Academic Research Vol. 3.No.2, 619 -623.

Gilman, L. (2012). Development of MI Theory. Paper submitted for Intelligence website. Retrieved from http:/www. Indiana.edu/-intell/mitheory.shtml.on 17/9/2012.

Government of Kenya, (2012).Re-Alignment of Education Sector to the Constitution of Kenya 2010:- Towards Globally Competitive Quality Education for Sustainable Development Nairobi: Government Printer

Göğebakan, D. (2003) How Students' Multiple Intelligences Differ in Terms Of Grade Level And Gender A Thesis Submitted To The Graduate School Of Social Sciences Of Middle East Technical University In Partial Fulfillment Of The Requirements For The Degree of Master of Science In The Department Of Educational Sciences September 2003

Golam, K. M. (2011). Professional Tendency And Multiple Intelligences Among 3rd Secondary Graders In AlBahrain Kingdom, Unpublished M. A. Thesis, University Of Bahrain, Al- Bahrain.

Hanafiyeh, M. (2013). The Relationship Between Iranian Learners' Multiple Intelligence And Success In Foreign Language Learning Asian. Journal Of Management Sciences And Education Issn: 2186-845x Issn: 21866-8441 Vol.2. No 1. Januay 2013 
Ishhq, H., Maqsood, A., Syed, A.M.\& Sardar, F. (2010). Perceptions of Students regarding Adaptability of MI at Elementary Level in Khyber Pakhtunkhula. Journal of Education and Sociology ISSN 2078-032x December 2010.

Johnson, K. \& White, J. (2002). The use of Multiple Intelligences in Criminal Justice. Education. Journal of Criminal Justice Education, 13 (2) pp 369-386.

Kalambuka, P. (2010). It is not KCPE exam we should worry about but a failed education system. The Daily Nation 17/12/2010. Opinion-Education Pg 13.Nairobi: TheNation Media Group Ltd.

Kamau, C. (2010). Find your career in your passion. The Standard 3/12/2010; Jobs and Careers. Pg 47. Nairobi: The Standard Group Centre.

Kariuki, W. (2011). Change: Nontraditional careers suddenly become attractive. The Standard.1/06/2011; Education. Pg 30. Nairobi: The Standard Group Centre.

Khataybeh, A. M. \& Al-Bdor, A. (2006). The Impact Of Using Multiple Intelligences In Teaching Science On Acquiring Science Processes Among 7th Graders. The Journal Of Arab Gulf Message, Vol. 85, The Office Of Arab Education Of Gulf Countries, Al- Riyadh, 99-133.

Kerka, S. (2012). Multiple Intelligences and Career Development. Trends and Issues Alert. No. 8: Ohio. Clearinghouse on Adult, Career, and Vocational Education Retreived 10/8/2012

Kimani, G.\& Kinyanjui, J. (2012). Assessment of the Effectiveness of Bachelor of Education Programme (B.Ed Arts) in meeting job needs of Graduates of University of Nairobi. Research Paper. Retreivedwww2aau.org/-kimani.pdf 29/8/2012.

Kniveton, B.H. (2009). Influences and Motives on which students base their choice of career. Journal of Research in Education 72, 47-59.

Lin, S. (2009). Gender and Major Differences in Self-Estimates of different Aspects of Gardner's Multiple Intelligences: A study of the Undergraduate Pre-Service Teachers in Taiwan. Asian Social Science Vol.5, No.5. Retrieved www.ccenet.org/journal.html.

Loori, A.A. (2005). Multiple Intelligences. A comparative study between the preferences of males and females Social Behavior and Personality 33(1), 77-88.

Mantzaris, J. (2012). Adding a Dimension to Career Counseling. Focus on Basics 3 No.1, from http://ncsall.gseweb.harvard.edu/fob/1999mantzari.html 29/10/2012

Matto, H., Berry-Edwards, J., Hutchinson, E.D., Bryant, S. A.\& Waldbilling, A. (2006). Teaching Notes: An Exploratory Study on Multiple Intelligences and Social Work Education. Journal of Social Work, 42 (2), 405-416.

Mustafa, S.A.Y., Dr. Saleh Mohammad Abu Jado, S.M.A., \& Onoz, S. M.(2014) Types Of Multiple Intelligences among Undergraduate Students At Yarmouk University In Light Of Gardner's Theory International Journal Of Humanities And Social Science Vol. 4, No. 6; April 2014.

Morris, M. (2004). The Eight One: Naturalistic Intelligences. In J. Kincheloe (Ed), Multiple Intelligences Reconsidered. New York: McGraw-Hill.

Morris, C. (2012). Multiple Intelligences and Career Implications. Retrieved from http://miresearch.org/files/Know Thyself3.doc on 27/3/2012.

Multiple Intelligence Tests (2013).Online Resource. Retrieved29/10/2013 http:/www.nedprod.com/Niall_stuff/Intelligence_test.htlm.29/3/2013.

Mugenda A.G. (2011). Social Science Research: Theory and Principles. Kijabe: Kijabe printing Press.

Naderi, H., Abdullah, R. \& Aizan, H.T. (2008). Male Versus Female Intelligence among undergraduate Students: Does it Matter? Asian Journal of Scientific Research, 1: 539 - 543.

Nasser, R., Singhal, S.\& Abouchedid, H. (2006). How Youth in India and Lebanon rate their Intelligences. Journal of Social Science 2 (4), 93 -99.

Net, F., Ruiz, F. \& Turnham, A. (2008). Sex Differences In Self-Estimation Of Multiple Intelligences Among Portuguese Adolescents, High Ability Studies, Vol. 19, No. 2, 189-204.

Nofal, M. \& Heeleh, M. (2008). Differences In Multiple Intelligences Among 1st Year Students Of Higher Education Institutions At Unrwa In Jordan. The Journal Of Al-Najah For Research (Humanities Sciences), Vol. 22 (5), 1599-1623.

Obora, H. (2012). Talent Testing and Psychometric Kits to Identify ones Career early. retrieved from $w w w$. Acgt.com 23/12/2012.

Okatcha, R.J., Grigorenko, E., Nokes, C., Prince, R,. Bundy, D.A.,\& Sternberg, R.J. (2012). The Relationship Between academic and practical intelligence. A case study in Kenya. Intelligence Volume 29, Issue 5, September- October 2001, 401-418. Retrieved 15/12/12.

Okatcha, R.J., Grigorenko, E., Prince, R., Nokes, C., Geissler, P.W., Kenny, D.A., Bundy, D.A.\& Sternberg, R.J.(2012). The Organization of Luo Conceptions of Intelligence A Study of Implicit Theories in a Kenyan Village. International Journal of :Behavioral Development Vol. 25 No. 4, 367 -378. Retrieved $15 / 12 / 12$. 
Organization For Economic Co-Operation And Development (Oecd). 2003. Career Guidance And Public Policy: Bridging The Gap. Ioc/Ec/2003/5. (Paris).

Oriedo, M. (2011). ). Moving with the times in career choices. The Standard 1/06/2011; Education. Pg 29. Nairobi: The Standard Group Centre.

Orodho, A.J. (2012). Techniques Of Writing Research Proposals And Reports In Education And Social Science: Nairobi Kanezja Publishers.

Ozgen, K., Tataroglu, B. \& Alkan, H. (2011). An Examination of Multiple Intelligence domains and Learning Styles of Pre-Service Mathematics Teachers. Their Reflections on Mathematics Education. Educational Research and Reviews Vol. 6(2),168 -181.

Ozdemir, P., Guneysu, S.\& Tekkaya, C. (2006). Enhancing Learning through Multiple Intelligences. Journal of Biological Education, 40(2), 74 - 78.

Özturk, S, Nazan Yelkikalan N., Hacioglu, G., Kiray, A., Ezilmez, B., Soylemezoglu, E., Cetin, H., Sonme, R. (2014) Emotional Intelligence Characteristics Of Students Studying At Various Faculties And Colleges Of Universities. European Scientific Journal April Edition Vol. 8, No.8 Issn: 1857 - 7881 (Print) E - Issn 1857- 7431

Razmjoo, S.E. (2008). On the Relationship between multiple intelligences and Language Proficiency. The Reading Matrix Volume 8, No.2, September 2008.

Reggio, R.E., Murphy, S.E.\& Pirozzolo, F. (2002). Multiple Intelligences and Leadership. New jersey: Lawrence Erlbaum Associates, Inc.

Samora, M. (2010). Forget Trends, Base Career Choice on Your Abilities. The Daily Nation 20/12/2010: The Springboard Pg 6. Nairobi: The Nation Media Group Ltd.

Saricaoglu, A. (2009). A Study of Multiple Intelligences, Foreign Language Success and some selected variables. Journal of Theory and Practice in Education Vol.5, (2) 110-112.

Serin, N.B., Serin, O., Yavuz, A.\& Muhammedzade, B. (2009). The Relationship between the primary teachers' teaching strategies and their strengths in multiple intelligences, Procedia Social and Behavioral Sciences 1, 709 -712.

Saeedi1, N., Pazvari, M.H., Saeid Askari Masouleh, S.A., Mousavian, S.I., (2012) Studying The Influence Of Emotional Intelligence On Career Success J. 2012 (C) 2012, Textroad.

Salehi, M., \& Gerami, S. (2012) On The Relationship Between Multiple Intelligences And Achievement Among Engineering Students English For Specific Purposes World, Issn 1682- 3257, http://Www.EspWorld.Info, Issue 35, Vol. 12, 2012.

Shahzada, G., Ghazi S.R., Khan, H.N. \& Iqbal, S.(2011) Muhammad Nauman Shabbir Self-Perceived Multiple Intelligences Of Male And Female. Mediterranean Journal Of Social Sciences Vol. 2, No. 1, January 2011, Issn 2039-2117.

Shearer, C.B. (2004). Using A Multiple Intelligences Assessment To Promote Teacher Development And Student Achievement. Teachers College Record, 106(1), 147-162.

Shearer, C.B. (2009). Exploring the relationship between intrapersonal intelligence and University students Career Confusion. Implications for counseling Academic Success and School-to career transition. Journal of Employment 46, 52 - 61.

Shearer, C.B., \& Luzzo, D.A. (2009). Exploring the Application of Multiple Intelligence Theory to Career Counseling. Career Development Quarterly, September, 2009.

Shearer, C.B. (2007). Multiple Intelligence Development Assessment Scales. Kent Ohio. MI Research Consulting Inc.

Shearer, C.B. (2006).Math skill and multiple Intelligence: An investigation into the MI profiles of High school students with varying levels of math skill. Ohio: Multiple Intelligence Consulting Inc.

Shearer, C.B. (2006).Using a Multiple Intelligence Assessment to Facilitate Teacher Development. Kent Ohio. MI Research and Consulting, Inc.

Shariffudin, R.S. (2010). The pattern of Personality Types, Multiple Intelligence and Critical thinking Preferences for High Achievers. Malaysia Research paper Presented To Fakultipendidikan, Universititeknologi.

Sternberg, R.J. (2003). A Handbook of Intelligence. Cambridge: Cambridge University Press.

Terri, K.\& Nokelainen, P. (2008). Identification of Multiple Intelligences with the Multiple Intelligences Profiling Questionnaire III. Psychology Science Quarterly, Vol. 50(2), 206 - 221.

Tirri, K., Nokelainen, P.\& Ubani, M. (2006).Conceptual Definition and Empirical Validation of the Spiritual Sensitivity Scale. Journal of Empirical Theology, 19 (1), $37-62$.

Wagah, M.O., Indoshi, F.C.\& Agak, J.O. (2010). Factors that determine students' and Teachers' Attitudes towards Art and Design Curriculum. International Journal of Vocational and Technical Education. Volume 2 (1), 9-17. 
Wendy, J.B., \& Johnson, T. (2007). Sex Different in Mental Abilities masks the dimensions on which they lie. Intelligence., 35: 23 -39.

Wilson, L.O. (2010). Newer Views of Learning- Exploring the Ninth Intelligence Maybe.http:/www.uwsp.edu/Wilson/learning/ninethintelligence.htm on 22/12/2010.

Yamin, W. A. (2013). Types Of Mathematical Thinking And Its Relationship With Multiple Intelligences And The Desire In The Specialization And Achievement Among Tenth Graders In Palestine. Unpublished M.A Thesis, Al-Najah National University, Nablus, Palestine.

Yazdanimoghaddam, M. and Khoshroodi, B. S. (2010). The Relationship Between Teachers Teaching Efficacy And Their Multiple Intelligence. Journal Of Language And Translation, 1(2), 33-45. 